\title{
Mechanical Trenching Cultural Resources Survey: Proposed Emergency Bridge Repair at Peek Road Bridge City of Katy, Fort Bend County, Texas
}

Catherine L. Jalbert

Michael Hogan

Follow this and additional works at: https://scholarworks.sfasu.edu/ita

Part of the American Material Culture Commons, Archaeological Anthropology Commons, Environmental Studies Commons, Other American Studies Commons, Other Arts and Humanities Commons, Other History of Art, Architecture, and Archaeology Commons, and the United States History Commons

Tell us how this article helped you.

This Article is brought to you for free and open access by the Center for Regional Heritage Research at SFA ScholarWorks. It has been accepted for inclusion in Index of Texas Archaeology: Open Access Gray Literature from the Lone Star State by an authorized editor of SFA ScholarWorks. For more information, please contact cdsscholarworks@sfasu.edu. 


\section{Mechanical Trenching Cultural Resources Survey: Proposed Emergency Bridge Repair at Peek Road Bridge City of Katy, Fort Bend County, Texas}

\section{Creative Commons License}

\section{(c) (1) \&}

This work is licensed under a Creative Commons Attribution-NonCommercial 4.0 International License 


\section{Mechanical Trenching Cultural Resources Survey}

PROPOSED EMERGENCY BRIDGE REPAIR AT PEEK ROAD BRIDGE CITY OF KATY, FORT BEND COUNTY, TEXAS

July 8, 2019

Terracon Project No. 92197225

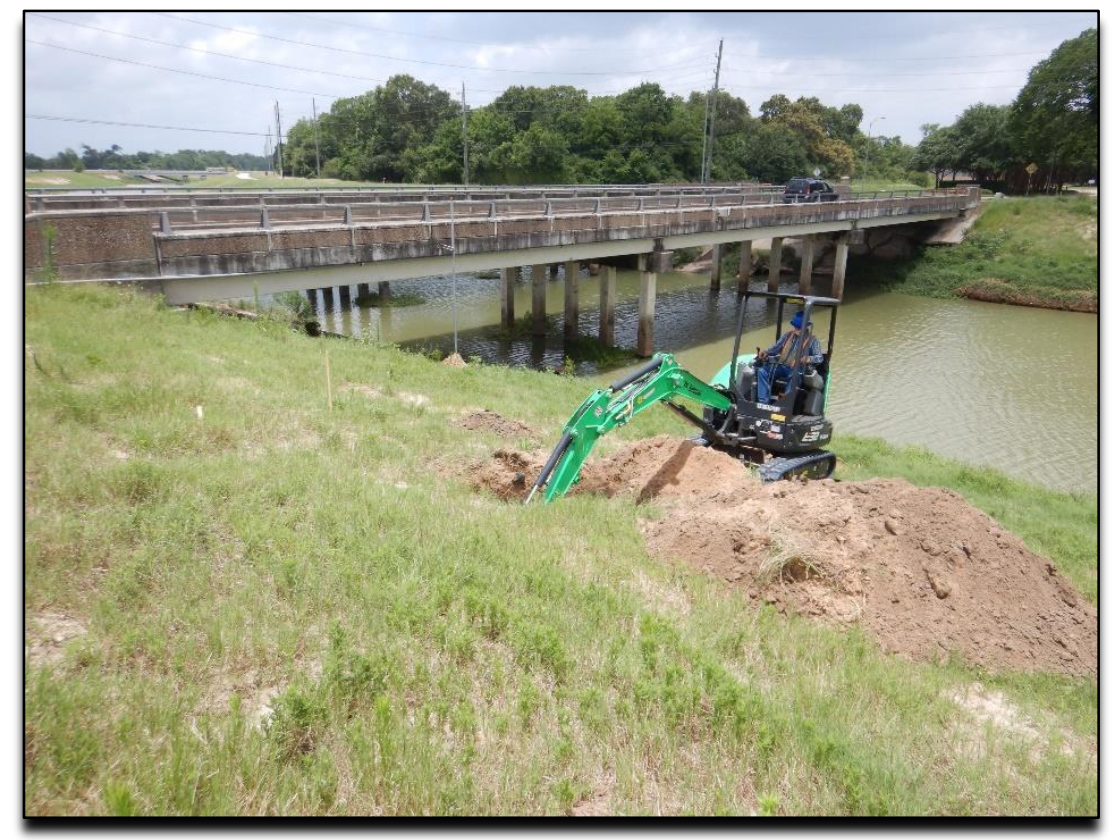

Prepared for:

CivilTech Engineering, Inc.

Cypress, Texas

Prepared by:

Catherine L. Jalbert, Ph.D., RPA and Michael Hogan, M.A.

Terracon Consultants, Inc. Houston, Texas

Principal Investigator: Jennifer Hatchett Kimbell, M.A., RPA TAC Permit: \#8904

\section{Terrecon}




\section{ABSTRACT}

Terracon Consultants, Inc. (Terracon) was retained by CivilTech Engineering, Inc. (Client) to conduct a mechanical trenching survey along the embankment slopes of Buffalo Bayou at Peek Road, the location of proposed emergency bridge repair in Katy, Fort Bend County, Texas. Since the proposed undertaking will occur on land owned or controlled by a political subdivision of the State of Texas, and because funding for this project will come, in part, from the Federal Emergency Management Agency (FEMA) this project required compliance with the National Environmental Policy Act (NEPA; Title 44, Part 10 CFR) and was subject to the Antiquities Code of Texas (Texas Natural Resources Code, Title 9, Chapter 191). This project was conducted under Antiquities Permit \#8904.

The proposed project area comprises an area approximately 200 feet wide, from high bank to high bank, and approximately 2,000 linear feet, consisting of 1,000 feet each upstream and downstream from the Peek Road bridge crossing (approximately nine acres). Terracon archeologists monitored the excavation of eight (8) trenches to the anticipated depth of impact (approximately five feet or one to two meters). One isolated find (a chert flake) was encountered during trenching. This artifact was recorded on site and not collected. Fieldwork was conducted between May 21 and May 23, 2019 by Jenni Hatchett Kimbell (Principal Investigator), Catherine Jalbert (Project Archeologist), and Michael Hogan (Staff Archeologist). The report was authored by Catherine Jalbert and Michael Hogan.

Given the absence of known archeological sites within the proposed project area, Terracon recommends no additional cultural studies are warranted at this time. In the event that human remains, historic properties, or buried cultural materials are encountered during construction or disturbance activities, work should cease in the immediate area but can continue where no cultural materials are present. Terracon, the THC's Archeology Division, or other proper authorities should be contacted. 


\section{TABLE OF CONTENTS}

ABSTRACT

1.0 INTRODUCTION AND MANAGEMENT SUMMARY ……...................................... 1

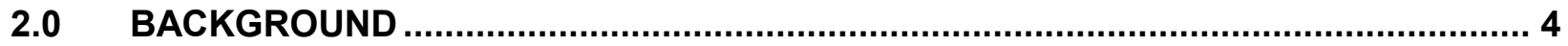

2.1 Environmental Setting .................................................................... 4

$2.2 \quad$ Culture History ...................................................................................... 4

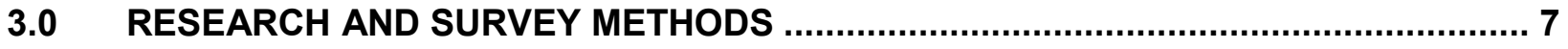

3.1 Desktop Review............................................................................... 7

3.2 Mechanical Trenching.............................................................................. 7

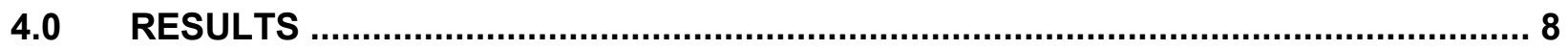

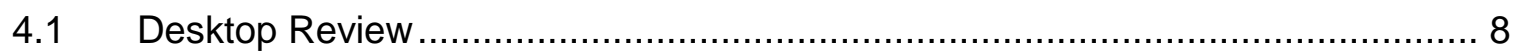

4.2 Mechanical Trenching ..........................................................................12

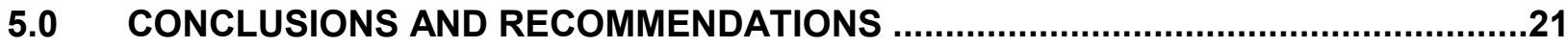

6.0 REFERENCES CITED

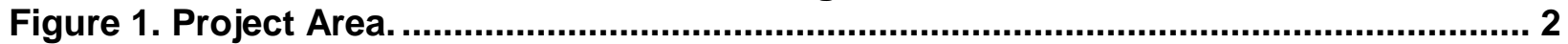

Figure 2. Project area on 2016 Richmond NE USGS 7.5' quadrangle.................................. 3

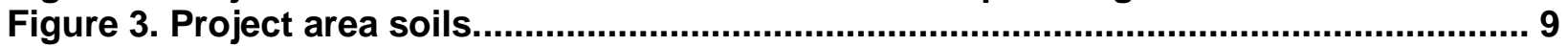

Figure 4. Project area PALM........................................................................................10

Figure 5. Results of desktop assessment. .........................................................................11

Figure 6. Trench locations................................................................................................13

Figure 7. Vegetation at Trench 1 location on north bank of Buffalo Bayou (facing southwest)...........................................................................................................14

Figure 8. Vegetation at Trench 8 location north bank of Buffalo Bayou (facing west).......14

Figure 9. Trench 1 (facing northeast). .........................................................................15

Figure 10. Trench 2 (facing north). ...................................................................................15

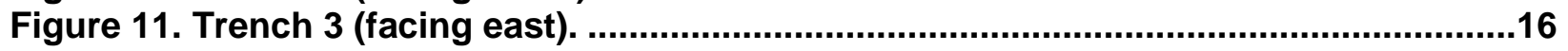

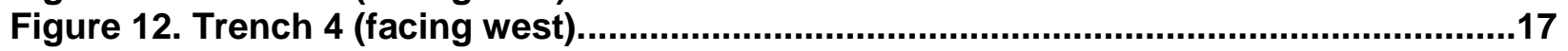

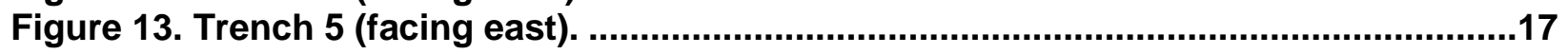

Figure 14. Southern half of Trench 6 (facing northwest) ...................................................18

Figure 15. Northern extent of Trench 6 (facing west)........................................................19

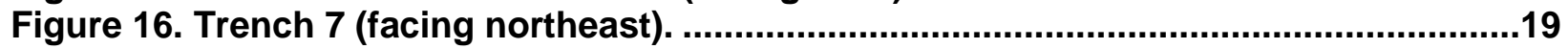

Figure 17. Ventral (left) and dorsal (right) surfaces of chert flake from Trench $7 \ldots \ldots \ldots \ldots . . .20$

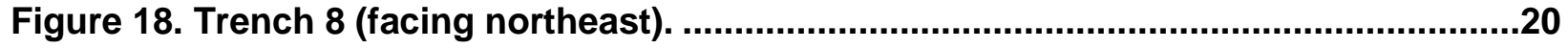

List of Tables

Table 1. Generalized culture history for Southeast Texas, with corresponding environmental periods. 5

\section{APPENDIX 1}




\title{
MECHANICAL TRENCHING CULTURAL RESOURCES SURVEY FOR EMERGENCY BRIDGE REPAIR AT PEEK ROAD, CITY OF KATY, FORT BEND COUNTY, TEXAS
}

\author{
Terracon Project No. 92197225
}

July 8,2019

\subsection{INTRODUCTION AND MANAGEMENT SUMMARY}

On behalf of CivilTech Engineering, Inc. (Client), archeologists from Terracon Consultants, Inc. (Terracon) monitored mechanical excavation on the embankment slopes of Buffalo Bayou adjacent to the Peek Road Bridge in Katy, Fort Bend County, Texas. (Figures 1 and 2). This investigation assisted the Client in complying with requirements triggered by Federal Emergency Management Agency (FEMA) involvement under the National Environmental Policy Act (NEPA; Title 44, Part 10 CFR) and the Antiquities Code of Texas (Texas Natural Resources Code, Chapter 191, and Texas Administrative Code, Title 13, Chapter 26).

The Area of Potential Effect (APE) of the Peek Road Bridge repair consists of an area 200 feet wide, from high bank to high bank, and 2,000 linear feet, 1,000 feet each upstream and downstream of the bridge crossing (approximately nine acres). Investigation of the project area consisted of sampling by means of backhoe trenching. This resulted in the excavation of eight (8) backhoe trenches. Seven trenches measured approximately four to five meters in length while one measured eight meters in length. Trenches measured one to two meters in width and were excavated to the anticipated depth of impact (approximately five feet). Fieldwork was performed between May 21 and May 23, 2019 and was conducted by Jenni Hatchett Kimbell (Principal Investigator) with the assistance of Catherine Jalbert (Project Archeologist) and Michael Hogan (Staff Archeologist). One isolated find, a chert flake, was recorded and not collected. Based on Terracon's investigations, no known archeological sites are present within the project area.

Given the absence of archeological sites within the project area, Terracon recommends that no additional work is warranted at this time. In the event that human remains, historic properties, or buried cultural materials are encountered during construction or disturbance activities, work should cease in the immediate area but can continue where no cultural materials are present. Terracon, the THC's Archeology Division, or other proper authorities should be contacted. 


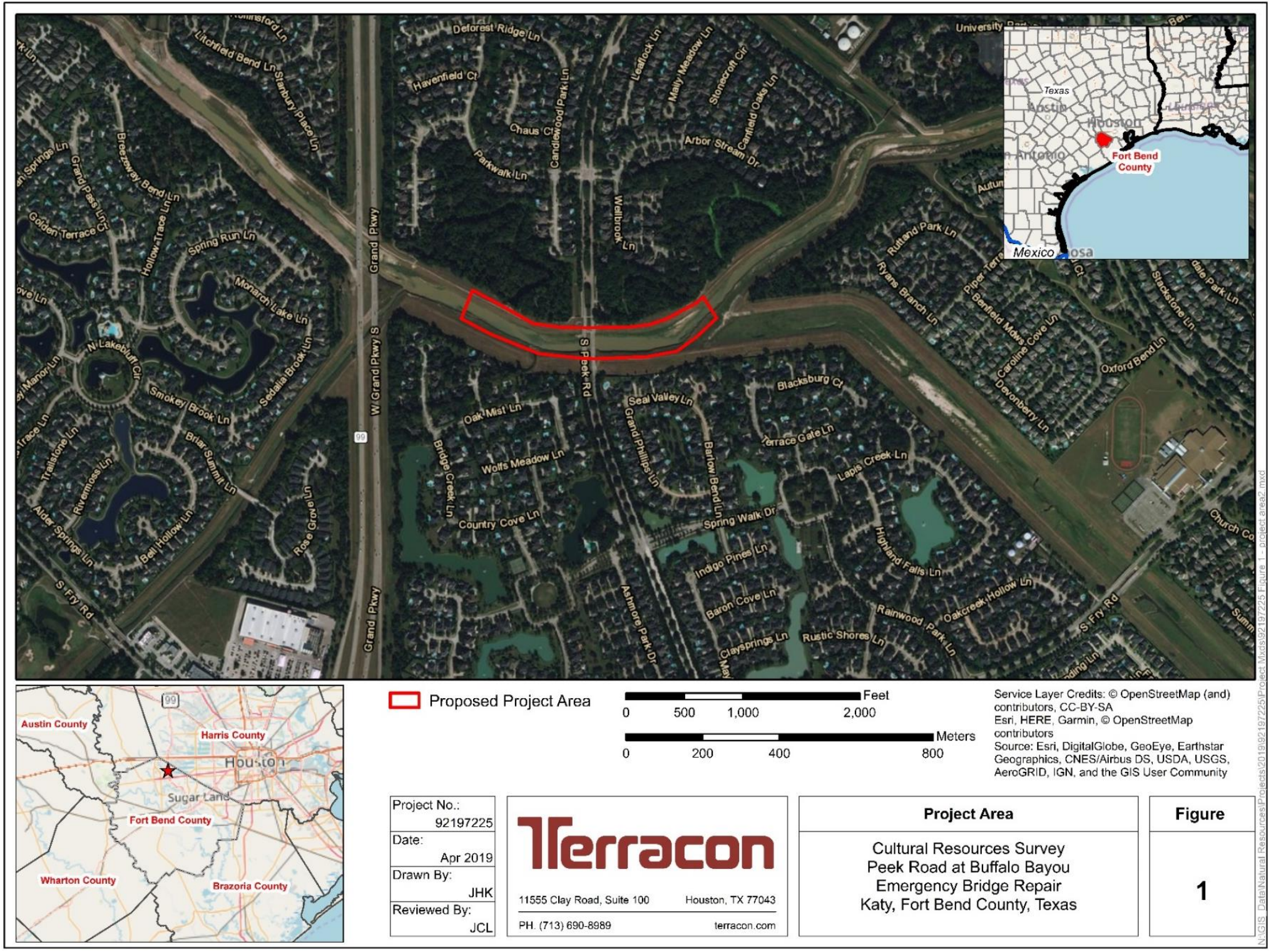

Figure 1. Project Area. 


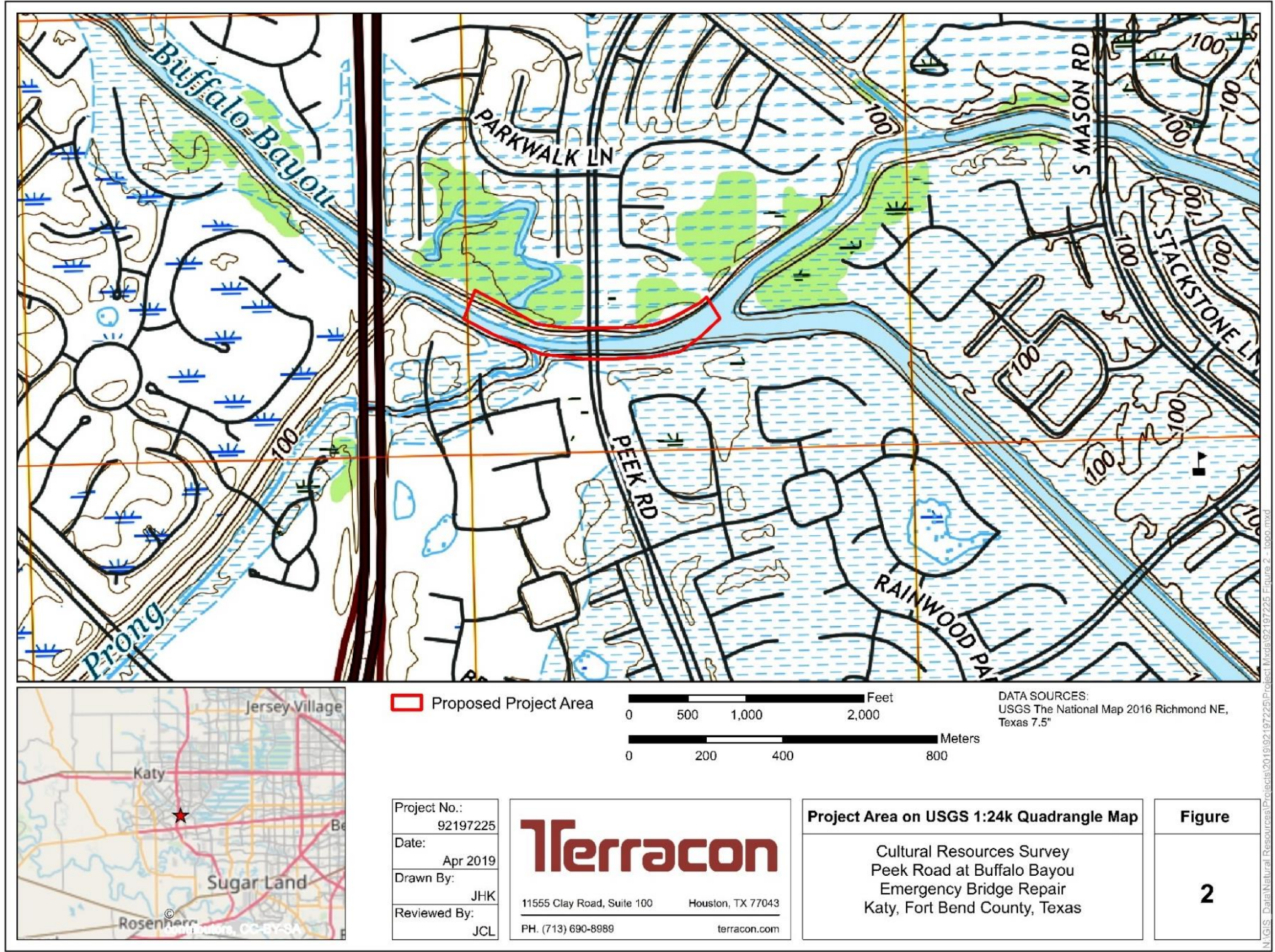

Figure 2. Project area on 2016 Richmond NE USGS 7.5' quadrangle. 


\subsection{BACKGROUND}

\subsection{Environmental Setting}

The project area, located in Fort Bend County, Texas, is in the Northern Humid Gulf Coastal Prairies of the Western Gulf Coastal Plain ecoregion (Griffith et al. 2007), which is characterized by generally flat, low relief prairie landscapes dominated by coastal aeolian processes and slowmoving drainages that feed into the Gulf of Mexico.

Fort Bend County, like the rest of southeast Texas more broadly, is characterized by long, hot summers with short, moderate winters. Overall, the climate and physiography are dominated by Gulf moisture, which provides the source for most rainfall, including periodic hurricanes and other major tropic storms. Average precipitation varies widely depending on the frequency and intensity of tropical storm systems and rainfall patterns. Rainfall totals can range from as much as 73 inches to as little as 18 inches per year (Griffith et al. 2007). Major storms, like Hurricane Harvey in 2017, can bring up to dozens of inches of rainfall in one event. Light freezes can occur between late November and early March. In between, average temperatures range from as low as $64^{\circ}$ in January to as high as $94^{\circ}$ in August.

The local biotic community is dominated by marsh and prairie grasses and forested stands, consisting of some pine and mixed hardwoods, found mostly on elevated sandy ridges between waterways. Elevation of the surrounding area is approximately 100 feet above mean sea level and Buffalo Bayou runs through the project area (see Figures 1 and 2).

\subsection{Culture History}

The project area is noted as the Southeast Texas archeological region (Aten 1983; Patterson 1995; Story et al. 1990). Various syntheses have been presented for this area, but many of them suffer from the poorly stratified nature of prehistoric sites in the area and poor preservation conditions which cause organic remains to degrade, leaving few samples available for radiocarbon dating. As a result, regional chronologies tend to be imprecise and vague.

Following Aten (1983), regional prehistory is typically divided into three general periods: Paleoindian (12,000 B.P. to 9000 B.P.), Archaic (9000 B.P. to 3000 B.P.), and Late PrehistoricWoodland (3000 B.P. to 250 B.P.). Generally, these stages or periods are based on a series of economic (including technology, subsistence, and settlement adaptations) transitions. To be sure, proposed shifts are related to climatic and environmental changes (Table 1), although these, like cultural transformations, are difficult to precisely date in the study area. 
Table 1. Generalized culture history for Southeast Texas, with corresponding environmental periods.

\begin{tabular}{|c|c|c|}
\hline Time Period & $\begin{array}{c}\text { Years Before Present } \\
\text { (calibrated years cal B.P.) }\end{array}$ & Environmental Period \\
\hline Historic & 250 cal B.P. to $\sim 1950$ & $\begin{array}{c}\text { Modern Era, sometimes referred } \\
\text { to as Anthropocene }\end{array}$ \\
\hline $\begin{array}{c}\text { Late Prehistoric- } \\
\text { Woodland }\end{array}$ & 3200 to 250 cal. B.P. & Early and Middle Holocene \\
\hline Archaic & 10,200 to 3200 cal. B.P. & Terminal Pleistocene \\
\hline Paleoindian & 13,800 to 10,200 cal B.P. & Latene \\
\hline
\end{tabular}

The Paleoindian period begins with the earliest evidence of human presence and occupation in the study area, and in the New World. Archeologists have argued that during this time, human bands were highly nomadic, relied heavily on hunting strategies for food and other important resources, and maintained cultural territories covering large expanses of terrain. Exploitation of now extinct Pleistocene fauna (including antique bison, mammoth, mastodon, and other taxa) was common. Subsistence data, however, also show reliance on small game including rodents and turtles. This period, covering nearly 4,000 years, saw many important adaptations that led in short order to the definition and establishment of regional cultural traditions, reduced settlement mobility, and increased populations across the region. Diagnostic tool types for the early part of this period include Clovis and Folsom points, both of which are defined by sophisticated fluting techniques. Fluted points eventually gave way to other forms including San Patrice, Dalton, Scottsbluff, St. Mary's Hall, and others (Lohse 2013; Ricklis 2004).

Approximately 10,200 years ago or more, Pleistocene climates underwent rapid warming; this marks the beginning of the Holocene and of many of the so-called Archaic adaptations that followed. Megafauna became extinct, either from over-predation or climate change or both, and environmental habitats changed as rainfall regimes increased and sea levels rose in response to glacial melt. The predominating cultural patterns associated with this transition are the demonstrable increase in reliance on plant resources both for tools and for subsistence. Almost certainly, the perceived emphasis on plants is related in part to poor preservation of Pleistocene remains. Nevertheless, with the loss of most large-bodied prey species from the landscape, socially defined food-getting and economic strategies became refocused on smaller prey and a wider variety of caloric resources (Story et al. 1990). An important archeological indication of this shift is the appearance of plant cooking technology that used thermally heated rocks as a source of heat to transform carbohydrates into ingestible sugars (i.e., caloric energy) (Thoms 2009). This technique immediately made available several geophytes, root-based plant resources as reliable sources of food. Throughout the Archaic, regional populations increased, albeit slightly, and some indications suggest increased interaction with other, distant regions. Southeast Texas never appears to have been directly linked into thriving or well-defined cultural patterns that covered large area. Yet regional adaptations remained persistent and constant. One exception involves the Calf Creek interval, dated to about 5950-5700 cal B.P. This brief period is defined by a sudden and intensive focus on bison hunting and followed a long period during which bison were absent from the study area. Calf Creek remains are found from western Louisiana across Texas and as 
far north on the Southern Great Plains as Kansas, eastern Colorado, Missouri, and western Arkansas (Thurmond and Wyckoff 1999).

The end of the Archaic in Southeast Texas corresponds with what Story et al. (1990) have termed the Mossy Grove archeological culture. In neighboring regions to the east, this period is called Woodland; each is defined by the appearance of pottery (first Tchefuncte then Goose Creek), but Woodland sites also commonly have domesticated plants, which appear to be absent from Mossy Grove assemblages. In terms of chipped stone tools, Gary points are ubiquitous across the region, and appear to last for an extended period. It seems likely that subtle variations within Gary point manufacturing and morphology might be discernable at sites where stratigraphic separation allows for such changes to be recognized. Following Costa et al. (2018), the last approximately 2,000 years of Southeast Texas prehistory might be best understood through a tripartite Mossy Grove sequence that reflect ceramic, lithic, and social developments. Under this recent scheme, Early Mossy Grove (EMG) begins with the appearance of pottery, probably diffusing westward from the Lower Mississippi Valley. This process extends until the appearance of the bow and arrow, perhaps around 1,200 years ago; this marks the beginning of so-called Middle Mossy Grove (MMG). This also marks the beginning of what is more commonly referred to as the Late Prehistoric period. Late Mossy Grove (LMG) reflects the eastern spread of a Plains-based economic system focused on the exploitation of bison, which appeared again in the study area for perhaps the first time since Calf Creek times.

Beginning in the early 1500s, European expeditions and incursions into Southeast Texas become increasingly frequent and included both French and Spanish influences. As these foreign powers competed for influence in the region, they encountered Native groups including the Atakapa, Akokisa, Bidai, Karankawa, Tonkawa, and others who had been in the area for centuries or longer (Aten 1983). Not long after Mexico gained its independence from Spain, in 1821, it began authorizing Anglo settlement into its northern territory of Tejas y Coahuila. San Felipe de Austin was established by Stephen F. Austin in 1824, in nearby present-day Austin County, as the colonial capital of this northern area, and it was from here that numerous land grants were issued to frontier settlers from the United States who came seeking new opportunities. Fifty-three of the Old Three Hundred, the settlers who followed Stephen F. Austin to Texas, were granted land in modern day Fort Bend County (Ott 2018). Even though slavery was illegal in Mexico, many of the new arrivals did indeed bring enslaved persons with them. After Texas won its independence from Mexico and until after the Civil War, much of the economic prosperity of the state, and particularly of Brazoria, Wharton, Fort Bend, and parts of Harris County, relied heavily on labor from enslaved persons (Brown 1994). The 1860 United States census counted 6,143 persons in Fort Bend County that year; 4,127 were slaves and 2,016 were white. Fort Bend planters voted 486 to 0 in favor of secession (Ott 2018). Reconstruction Era Fort Bend County was a hotbed of conflict between Republicans and Democrats, eventually led to the Jaybird-Woodpecker War where the Democrat Jaybirds forced the Republican Woodpeckers out of the county in 1889 (Yelderman 2010). The city of Katy was founded in 1895 along the Missouri, Kansas, and Texas Railroad. 


\subsection{RESEARCH AND SURVEY METHODS}

A combination of desktop review and archeological fieldwork was employed to identify cultural resources present within both the project area and a half-mile study area. Desktop review within the half-mile study area focused on identifying previously recorded cultural resources, while mechanical trenching within the project area was used to locate previously unknown, deeply buried archeological resources.

\subsection{Desktop Review}

The desktop review was conducted by consulting United States Department of Agriculture (USDA) Natural Resources Conservation Service (NRCS) soils data; TxDOT's Potential Archeological Liability Map (PALM); the Texas Historical Commission's online database, the Texas Archeological Sites Atlas (Atlas), which is restricted to qualified archeologists; United States Geological Survey (USGS) topographic maps and other historic maps; the National Register of Historic Places (NRHP) website; the Texas Freedom Colonies Atlas; TxDOT electronic resources for historic sites and bridges; and aerial photographs. These sources provide information on factors that affect the likelihood of intact archeological deposits being present, previous recorded archeological investigations, recorded prehistoric or historic-period sites, and recorded historic properties listed in or eligible for listing in the NRHP within and near the project area. It should be noted that, while the Atlas includes polygons and lines representing many of the archeological investigations undertaken over the last five decades or so in Texas, this aspect of the Atlas is lacking much information. Additionally, the information available varies widely in quality, detail, and accuracy; this is particularly true for investigations conducted more than about 20 years ago.

\subsection{Mechanical Trenching}

Terracon archeologists sampled the project area by means of backhoe trenching to reach archeological deposits deeper than what can be achieved by shovel testing. Four (4) trenches were excavated on either side of the crossing and were roughly spaced to broadly sample the project area for buried deposits. Trenches measured approximately four to five meters (with one measuring eight meters) in length and were excavated to a depth corresponding with the anticipated depth of impacts (approximately five feet). Trenches were excavated in accordance with OSHA standards for trench safety. Trenches were excavated in vertical levels each measuring approximately one foot in thickness and removed parallel with the observed stratigraphy. Trench deposits were sampled for cultural remains by passing five 5-gallon buckets of sediment per level through $1 / 4$-inch screen. Any artifacts or other cultural items were described and recorded on site and then returned to the units after being placed into a plastic, zip-lock bags inscribed with the trench number and level number from which they it came. 


\subsection{RESULTS}

\subsection{Desktop Review}

The project area is located within an area that is primarily comprised of Snakecreek series fine sandy loam, zero to one percent slopes, and Katy series fine sandy loam, zero to one percent slopes. These soils are characterized as somewhat poorly drained Holocene-age alluvium common to coastal plains and drainageways. These soils formed in loamy sediments derived from the Pleistocene-age Lissie Formation (Figure 3).

An examination of the TxDOT Potential Archeological Liability Map (PALM) for the Houston area reveals that the project area is within an area mapped as Map 3A. Due to the high likelihood of deep deposits in areas represented by Map 3A, deep reconnaissance rather than shovel testing is recommended, particularly when deep impacts are expected (Figure 4). The PALM models incorporate many factors to provide some guidance regarding the likelihood that prehistoric archeological sites will be preserved in the three feet below the surface or at deeper levels within mapped areas.

Terracon accessed the Atlas on May 30, 2019 and assessed the project area and the area within one-half mile of the project area for the presence of previously recorded archeological investigations and previously recorded archeological sites, including sites listed in or eligible for listing in the NRHP, as well as cemeteries and significant historic sites. The Atlas revealed one site adjacent to the project area and several others within a one-half mile buffer (Figure 5). The closest recorded archeological site is 41FB140, a buried prehistoric lithic scatter recorded in 1987 on behalf of the Environmental Protection Agency (EPA) in support of the Cinco Ranch Venture project conducted by Espey, Huston and Associates, Inc. This site is located approximately 95 feet (or 30 meters), north of the project area. This site contained intact buried deposits and included four lithic flakes. Other sites that exist within one-half mile of the project area include 41FB137, 41FB138, 41FB139, 41FB183, and 41FB186. These were noted to be prehistoric sites with intact buried deposits and likewise were recorded as part of the Cinco Ranch Venture project. Sites 41FB183 and 41FB186 were recorded by Moore Archaeological Consulting, Inc. in 1988 and consisted of two flakes and some pottery fragments, indicative of the Late Prehistoric period. Sites 41FB137, 41FB138, and 41FB139 were recorded by Espey, Huston, and Associates, Inc. and contained a small number of lithic flakes and one arrow point (41FB139).

The Texas Freedom Colonies Atlas (2019) was consulted, and there are no listed freedom colonies known in or near the project area. Additionally, there are no recorded cemeteries, State Antiquities Landmarks, or NRHP-listed properties located within or near the project area. Topographic maps $(1955,1971,1980)$ were reviewed for the purposes of identifying potential historic structures. The project area is situated on the Richmond NE 1:24,000 USGS topographic quadrangle map. No historic resources within or near the project area were identified on these maps. Additionally, aerial imagery dating to 1944 from Google Earth ${ }^{\mathrm{TM}}$ was reviewed and did not reveal apparent structures in the project area. 
Mechanical Trenching Cultural Resources Survey

CivilTech Engineering, Inc., Peek Road Bridge $n$ Katy, Fort Bend County, Texas

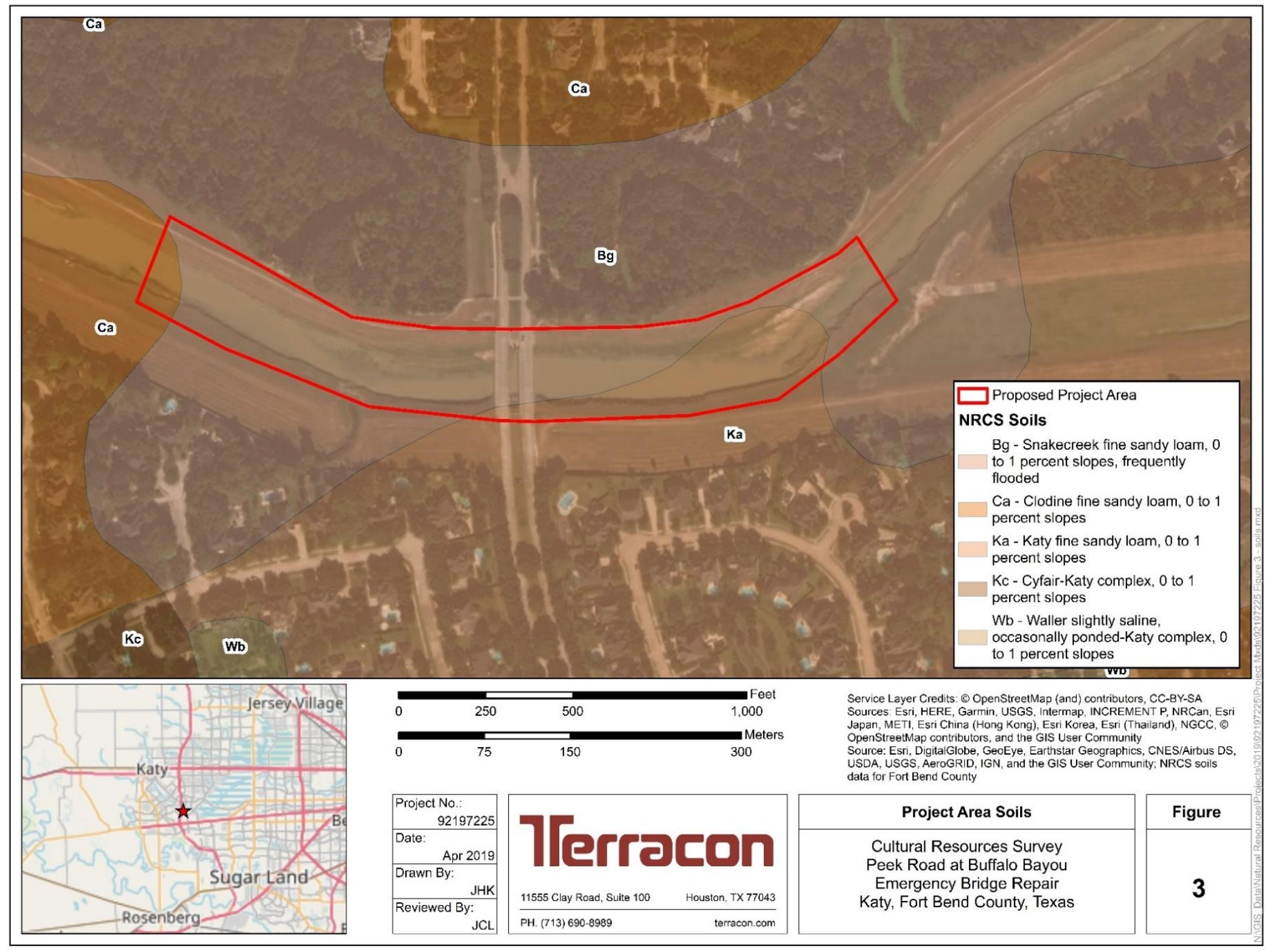

Figure 3. Project area soils. 
Mechanical Trenching Cultural Resources Survey

CivilTech Engineering, Inc., Peek Road Bridge $\approx$ Katy, Fort Bend County, Texas July 8, 2019 - Terracon Project No. 92197225

\section{Terracon}

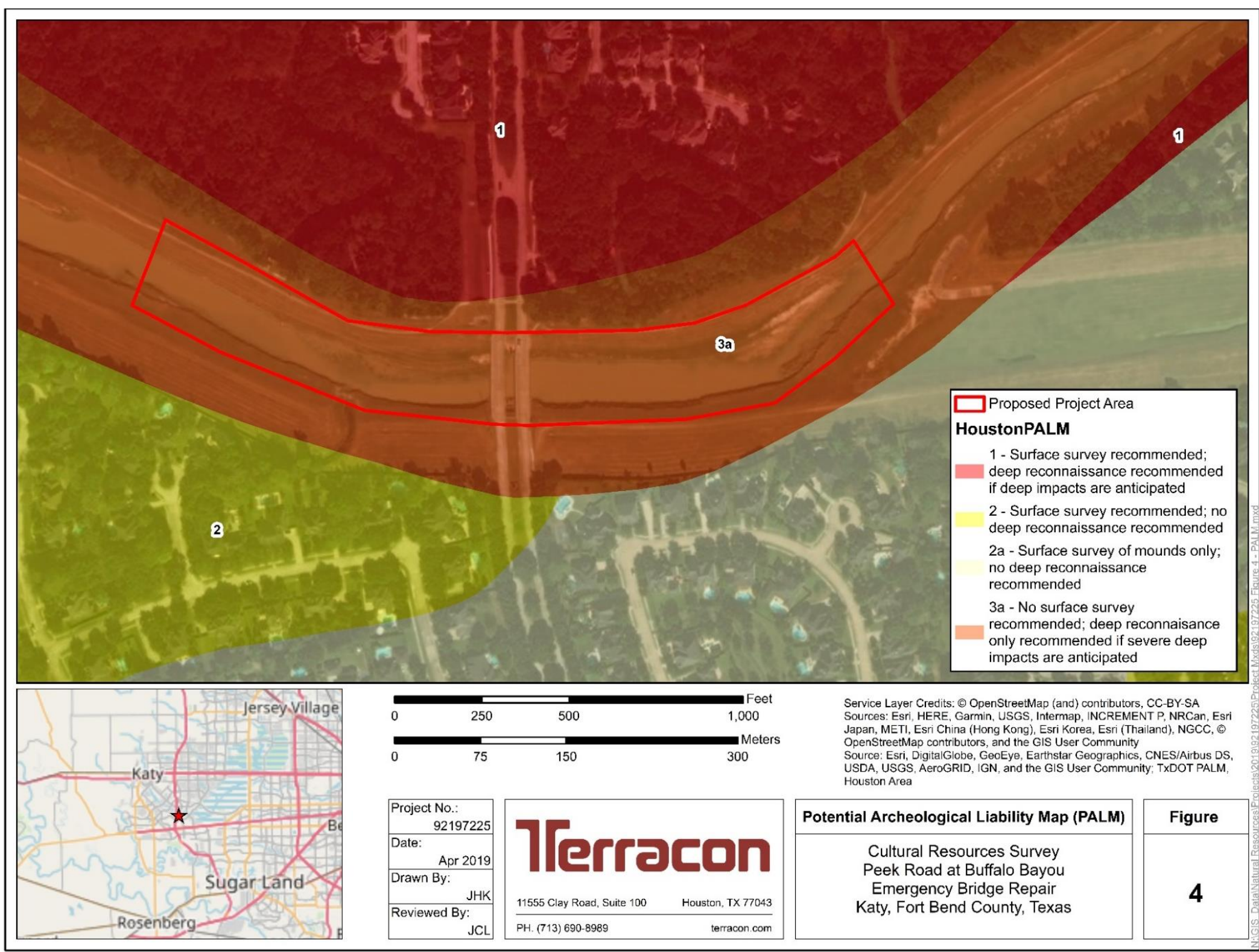

Figure 4. Project area PALM. 
Mechanical Trenching Cultural Resources Survey

CivilTech Engineering, Inc., Peek Road Bridge $\approx$ Katy, Fort Bend County, Texas

July 8, 2019 - Terracon Project No. 92197225

Figure Redacted for Site Protection

Figure 5. Results of desktop assessment. 


\subsection{Mechanical Trenching}

The mechanical trenching cultural resources survey consisted of the excavation of eight backhoe trenches (Figure 6). The project area was primarily characterized by a steep slope (approximately 25 degrees) with low, well-maintained grass along the banks of Buffalo Bayou (Figures 7 and 8). Surface visibility ranged between 30 and 50 percent. Most trenches were excavated perpendicular to the bayou. Trenches measured four to five meters in length except for Trench 6 , which measured eight meters in length. A sampling of trench sediments from each trench (five 5gallon buckets) was screened through 1/4" mesh for cultural materials. Trench profiles are illustrated in Appendix 1.

Trench 1: This trench was located toward the top of the bank in the northeastern section of the project area and was orientated east/west. Stratum I is represented by a narrow band of loose, light yellowish-brown sand with clay inclusions; this stratum is likely alluvium deposited during recent flooding events related to Hurricane Harvey and was common to all trenches excavated in the project area. Stratum II consisted of fill represented by dry, mottled clay (Figure 9). It is probable that this stratum relates to construction of the walking trail that follows the path of Buffalo Bayou or as a result of the Cinco Ranch subdivision located to the north of this trench. Stratum III is a possible illuviation of brown sandy clay loam in Stratum II. Stratum IV is a narrow layer of compact light brownish gray silt underlain by Stratum V, a compact, dry, very dark brown clay. No cultural materials were observed in Trench 1.

Trench 2: Trench 2 was located just east of Peek Road and west of Trench 1. This trench was placed approximately halfway between the bayou and the top of the bank and was orientated east/west. Like Trench 1, Stratum I consists of a narrow band of loose, light yellowish-brown alluvial sand with clay inclusions. Stratum II consists of yellowish-brown sandy clay loam (Figure 10). Stratum III is a very dark grayish brown clay with approximately five percent redox concentrations. Stratum IV is represented by a similar soil color and composition to Stratum III, but Stratum IV has a much higher concentration of cylindrical redoximorphic features (approximately 40 percent). The interface between strata III and IV is diffuse. The base of the trench is represented by a light gray moist and friable sand that extends into the subsoil (Stratum V). No cultural materials were observed in Trench 2.

Trench 3: This trench was placed east of Peek Road near the top of the south bank of Buffalo Bayou in close proximity to the bridge crossing. This trench was orientated north/south, perpendicular to the bayou. Stratum I consists of friable, very pale sand with clay inclusions, a small percentage (approximately five percent) of gravels, and mussel shells throughout the stratum. Stratum II is a dark grayish brown sandy clay where the gravels and mussel shells persist; however, this stratum also included large amounts of modern plastic. Stratum III consisted of dark grayish brown clay with a small amount (approximately five to 10 percent) of redoximorphic mottling (Figure 11). No cultural materials were identified in Trench 3. 
Mechanical Trenching Cultural Resources Survey

CivilTech Engineering, Inc., Peek Road Bridge $\approx$ Katy, Fort Bend County, Texas

July 8, 2019 - Terracon Project No. 92197225

Figure Redacted for Site Protection

Figure 6. Trench locations. 


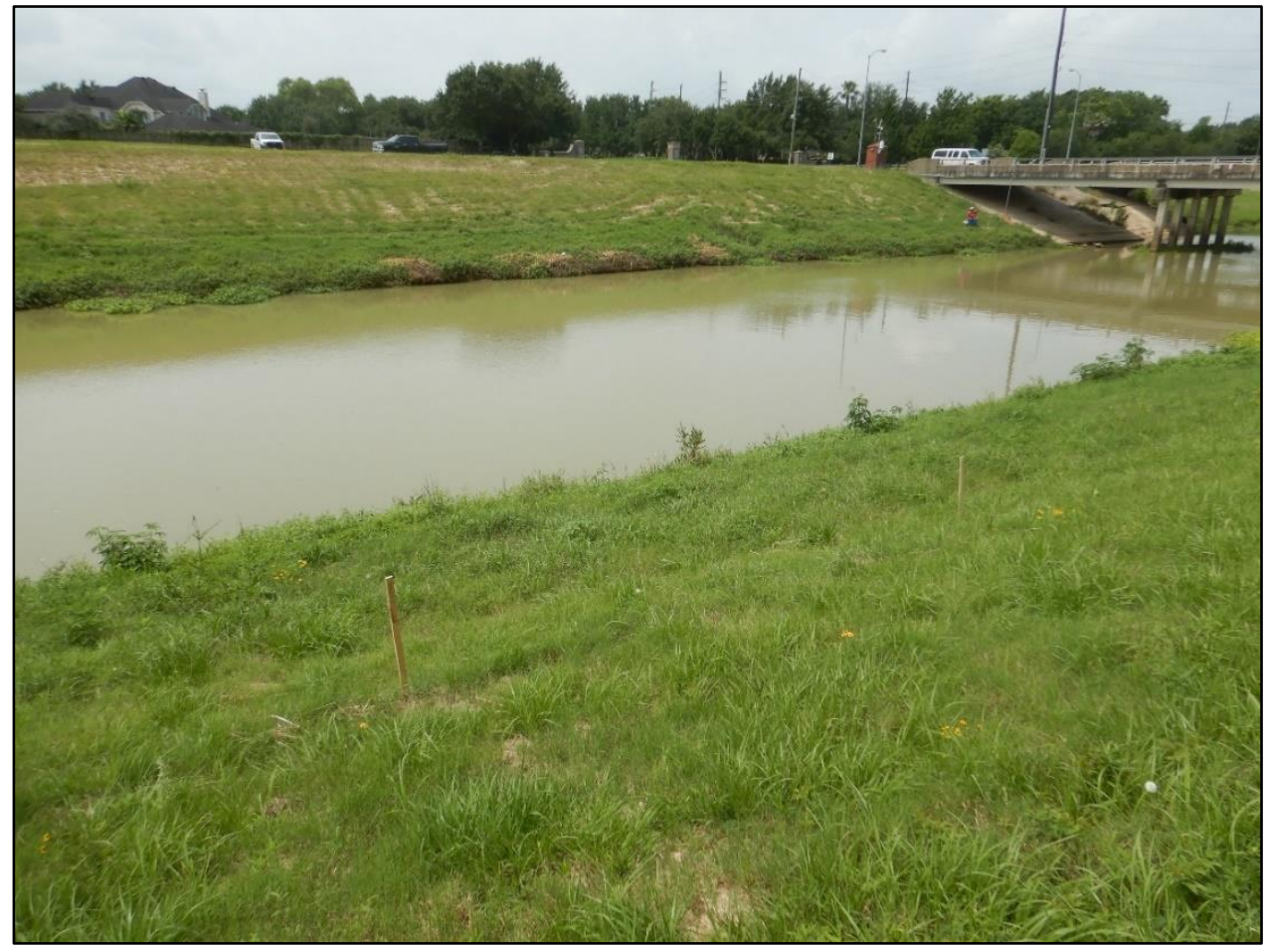

Figure 7. Vegetation at Trench 1 location on north bank of Buffalo Bayou (facing southwest).

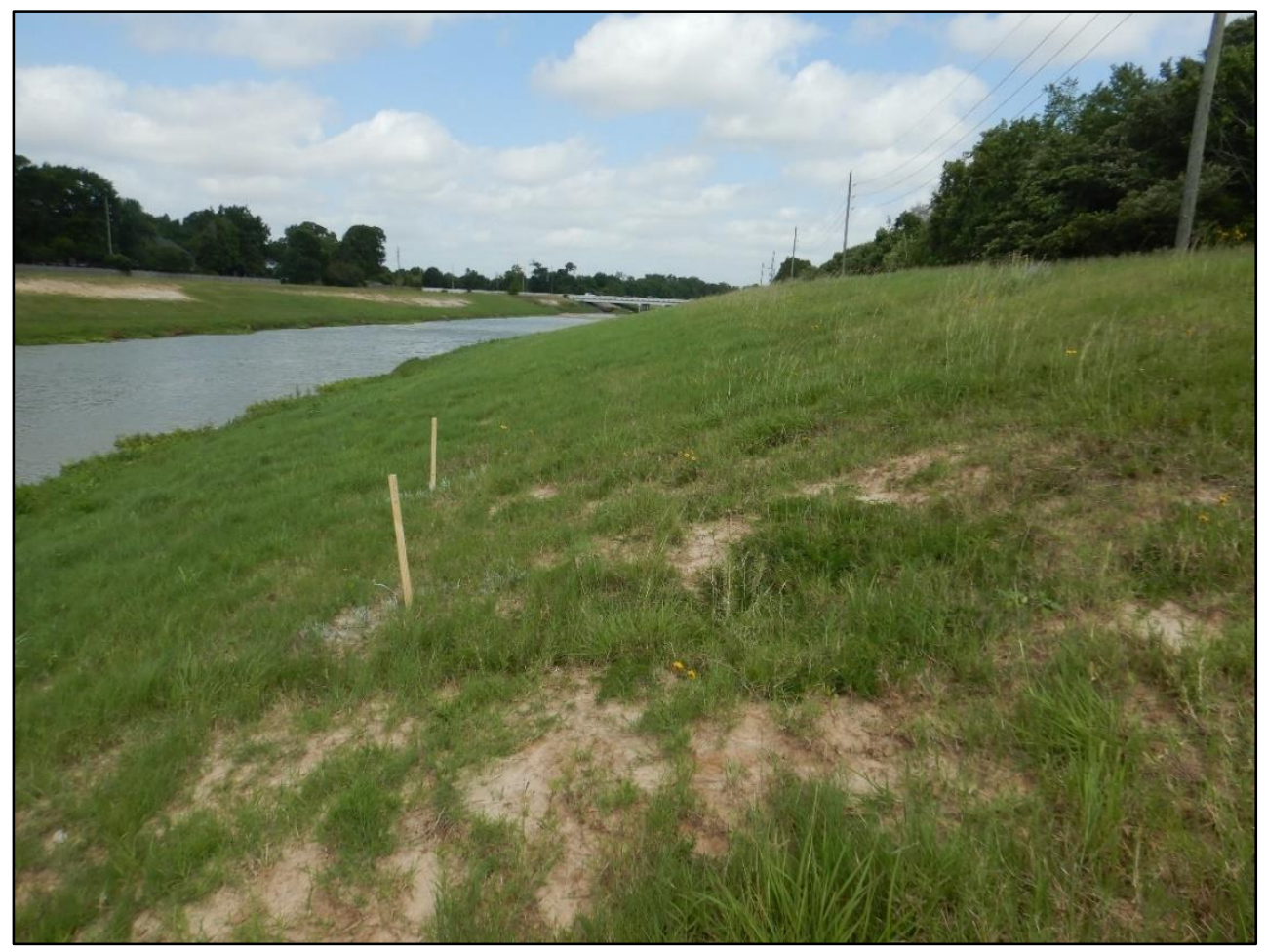

Figure 8. Vegetation at Trench 8 location north bank of Buffalo Bayou (facing west). 


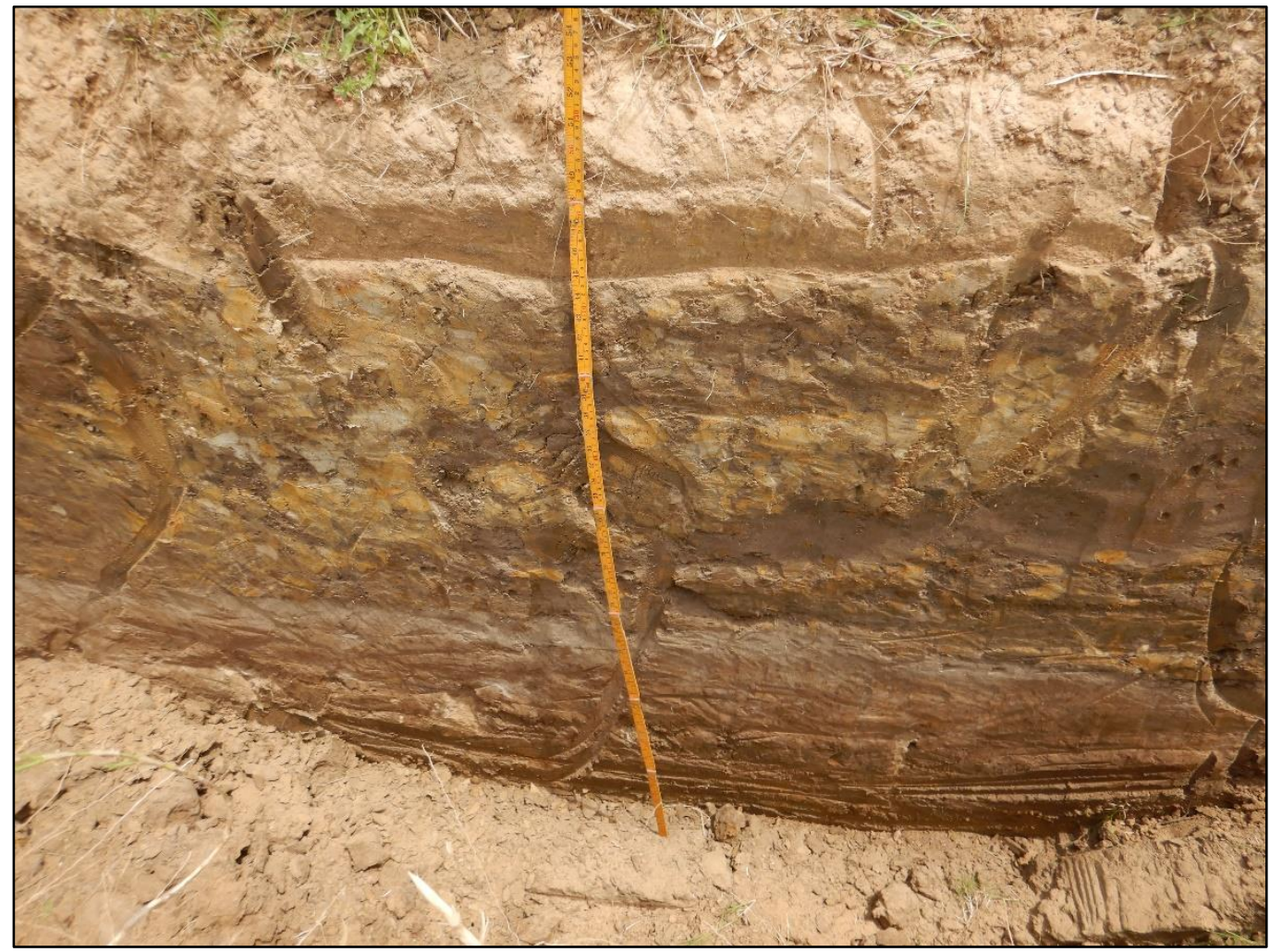

Figure 9. Trench 1 (facing northeast).

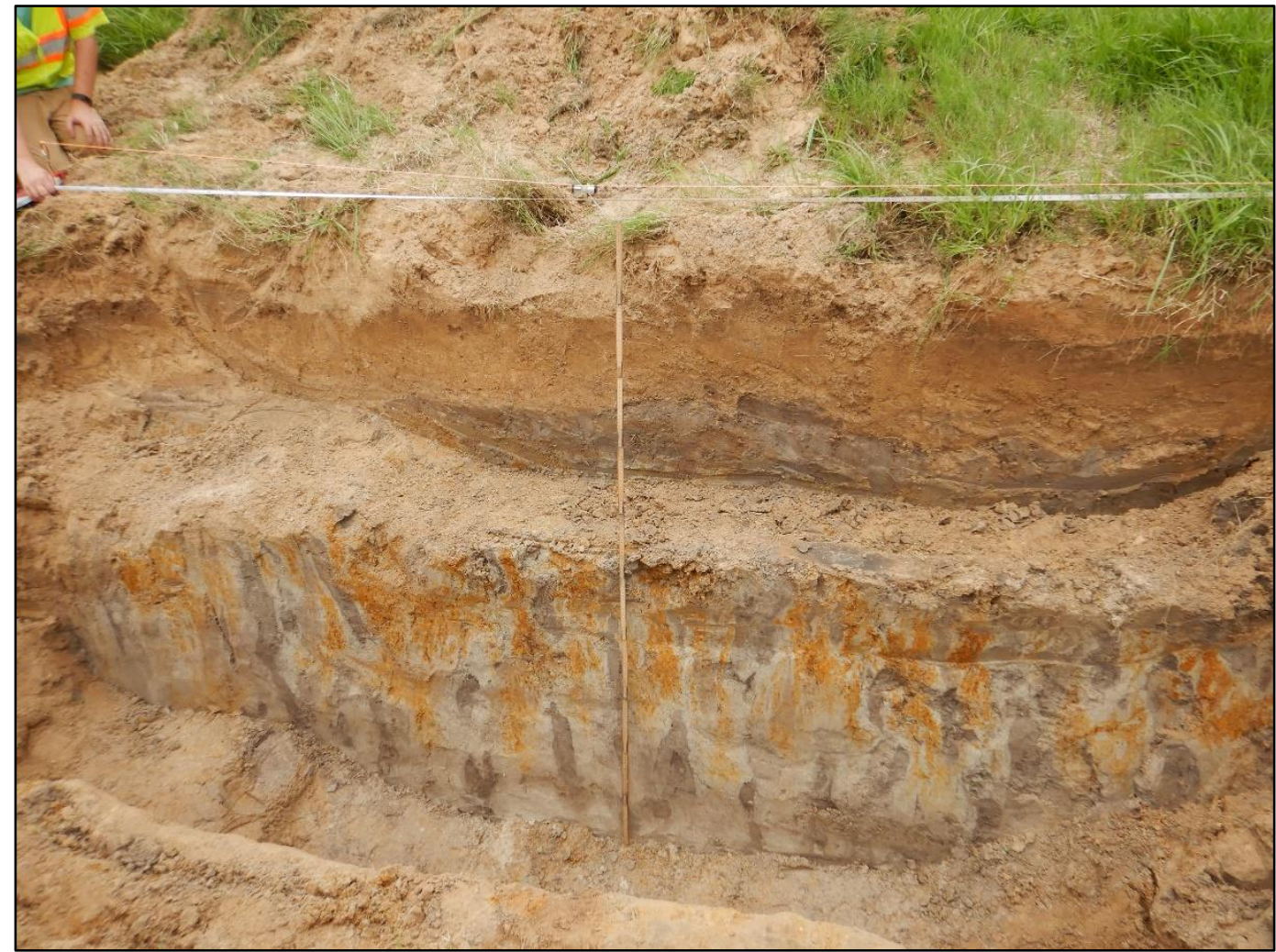

Figure 10. Trench 2 (facing north). 


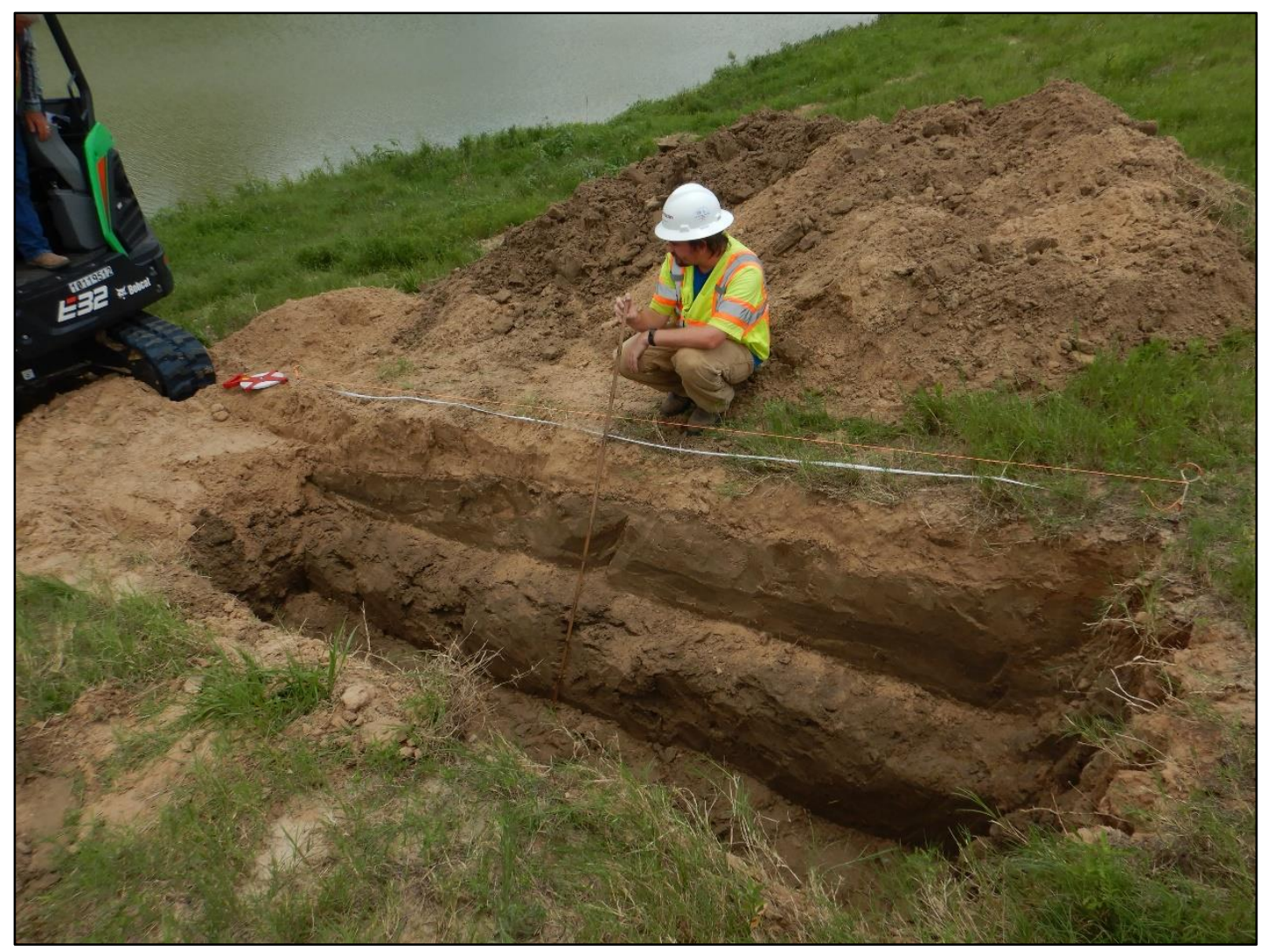

Figure 11. Trench 3 (facing east).

Trench 4: Trench 4 was located near the southeast corner of the project area approximately halfway up the bank and was orientated north/south. Again, Stratum I consists of a dry and loose light yellowish-brown alluvial sand with clay inclusions. Stratum II is a compact very dark brown clay subsoil that contained small pedular concentrations of calcium carbonate. Stratum III is a compact and dry very dark gray clay with redoximorphic staining (approximately 50 percent) and approximately one percent iron concretions (Figure 12). Stratum IV is a compact, brown loamy sand. Strata V, VI, and VII are narrow bands of very pale brown to light brownish gray sand/sandy loam layers. Stratum VIII is a heavily disturbed layer of fill near the top of the bank that was probably deposited during the construction of the nearby subdivision or for buried utility lines located on the plateau at the top of the bank. Strata IX, X, and XI are sandy matrices that range from dry and friable to compact. No cultural materials were identified in Trench 4.

Trench 5: This trench was located on the south bank of Buffalo Bayou west of Peek Road. Trench 5 was located approximately halfway up the bank and orientated north/south. Stratum I consists of a friable brown sandy clay loam that contained small, spherical iron concretions and calcium carbonate. Stratum II is a compact light brownish gray clay with redoximorphic concentrations (approximately 30 percent) and charcoal flecking throughout (Figure 13). Stratum III consisted of a moist, friable, light gray sand that appears to be near the water table. No cultural materials were observed in Trench 5. 


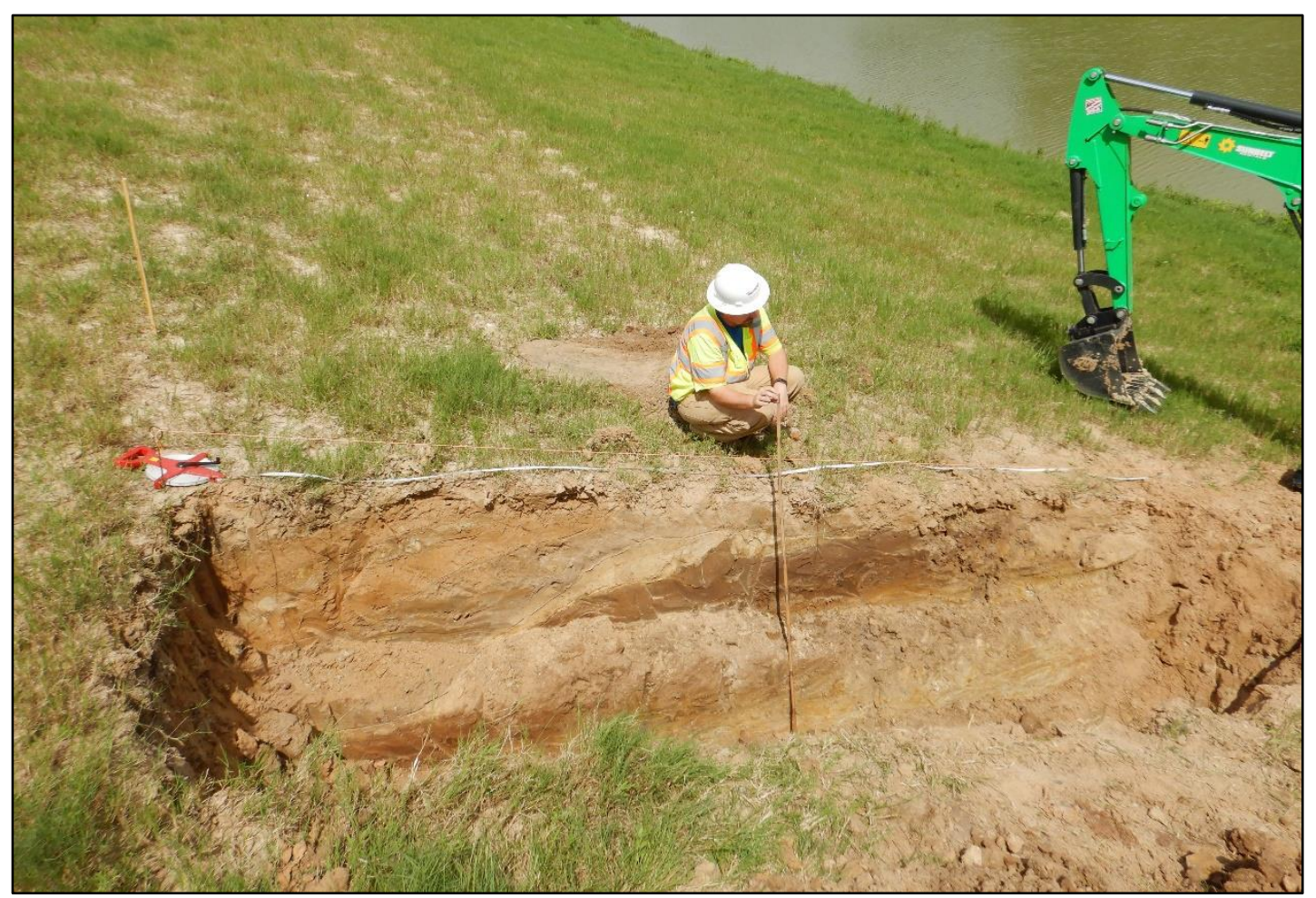

Figure 12. Trench 4 (facing west).

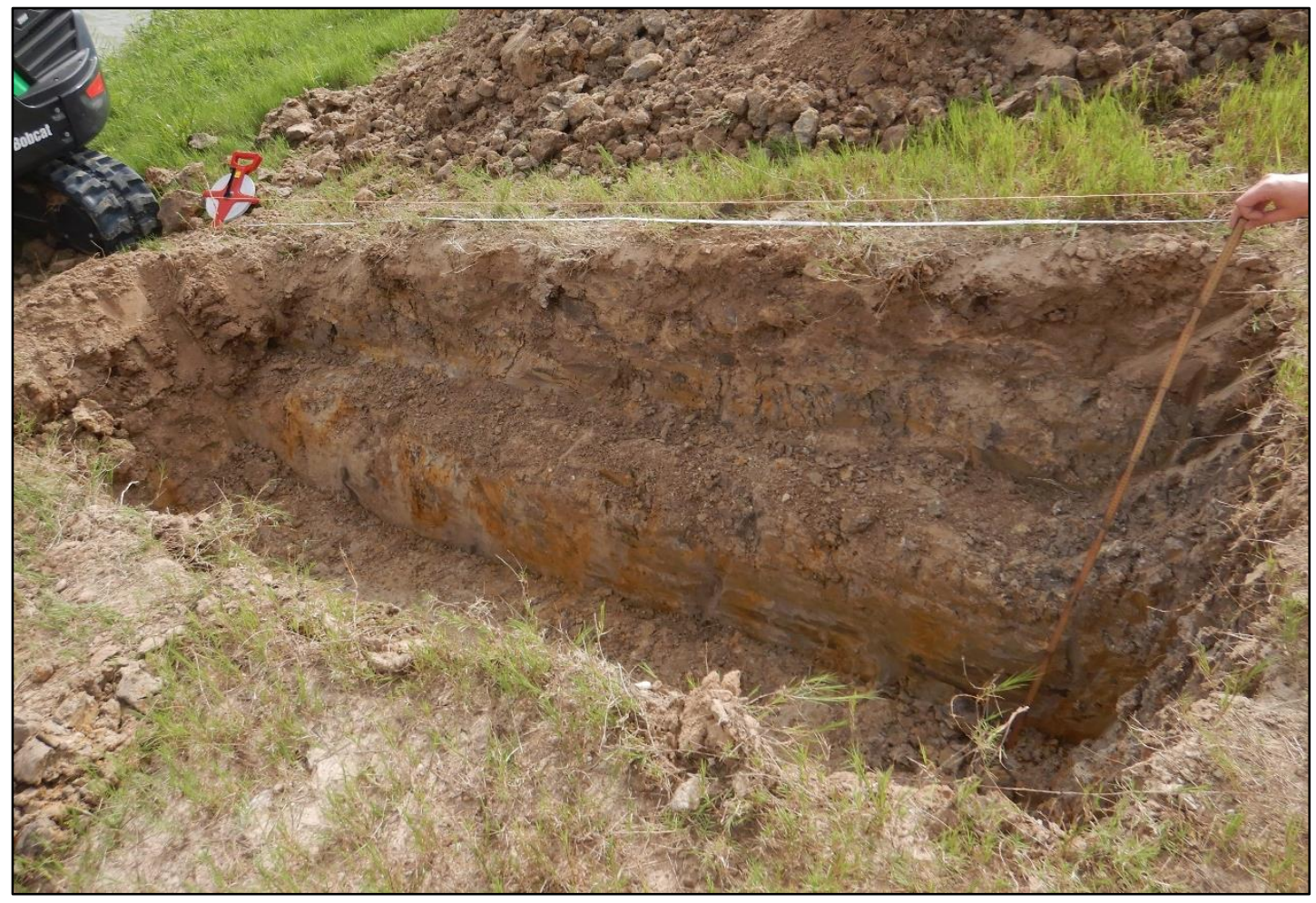

Figure 13. Trench 5 (facing east). 
Trench 6: Trench 6 was located near the southwest corner of the project area and measured eight meters in length (Figure 14). This trench was orientated north/south. Stratum I consisted of a narrow layer of loose brown sand with clay intrusions that is present only on the north end of the trench. Stratum II consisted of light gray compacted sandy clay loam with a small percentage (zero to two percent) of charcoal flecking. Stratum III is a fill layer present in the south end of the trench, farthest upslope, and consists of a very hard, compacted light yellowish-brown sandy clay. Stratum IV is present in the north end of the trench and is represented by a compact reddish clay substratum with pedular calcium carbonate (Figure 15). No cultural materials were identified in Trench 6.

Trench 7: Trench 7 was located near the top of the bank just west of Peek Road to the north of Buffalo Bayou (Figure 16). This trench was orientated north/south. Stratum I consists of very pale brown sand with clay inclusions while Stratum II is represented by a possibly buried humic layer consisting of very dark gray sandy clay loam. Stratum III underlies Stratum II and is a mottled sandy clay loam fill with varying sizes of gravels/rocks present. Stratum IV is a compact grayish brown sandy clay loam with charcoal flecking throughout. One isolated find, a chert flake, was recovered from this stratum at approximately 50 centimeters below surface (cmbs) (Figure 17). This find was documented and reburied in a plastic ziplock bag inscribed with the appropriate provenience information, as described in the survey methods above. No other cultural material was recovered from this trench.

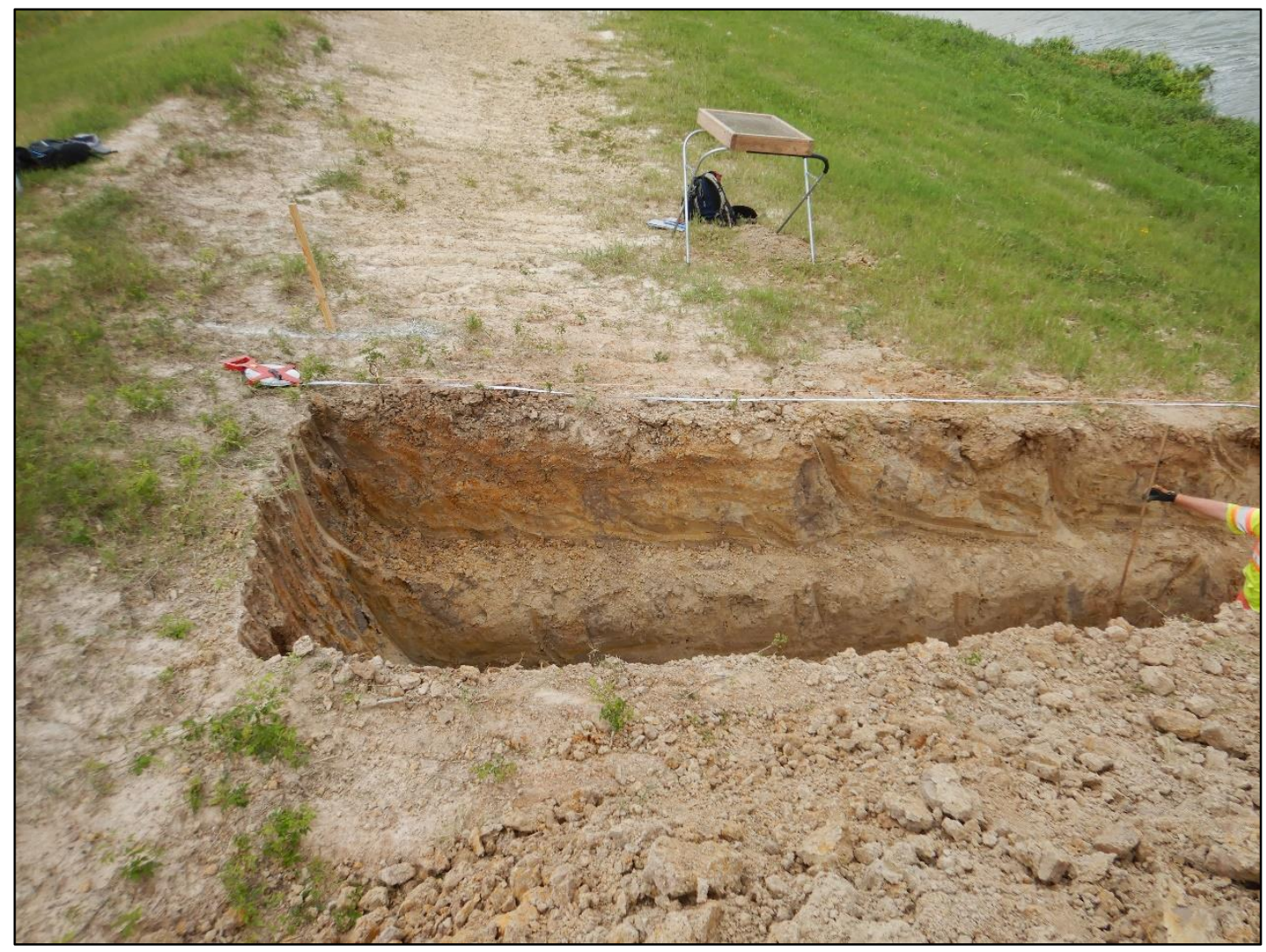

Figure 14. Southern half of Trench 6 (facing northwest). 


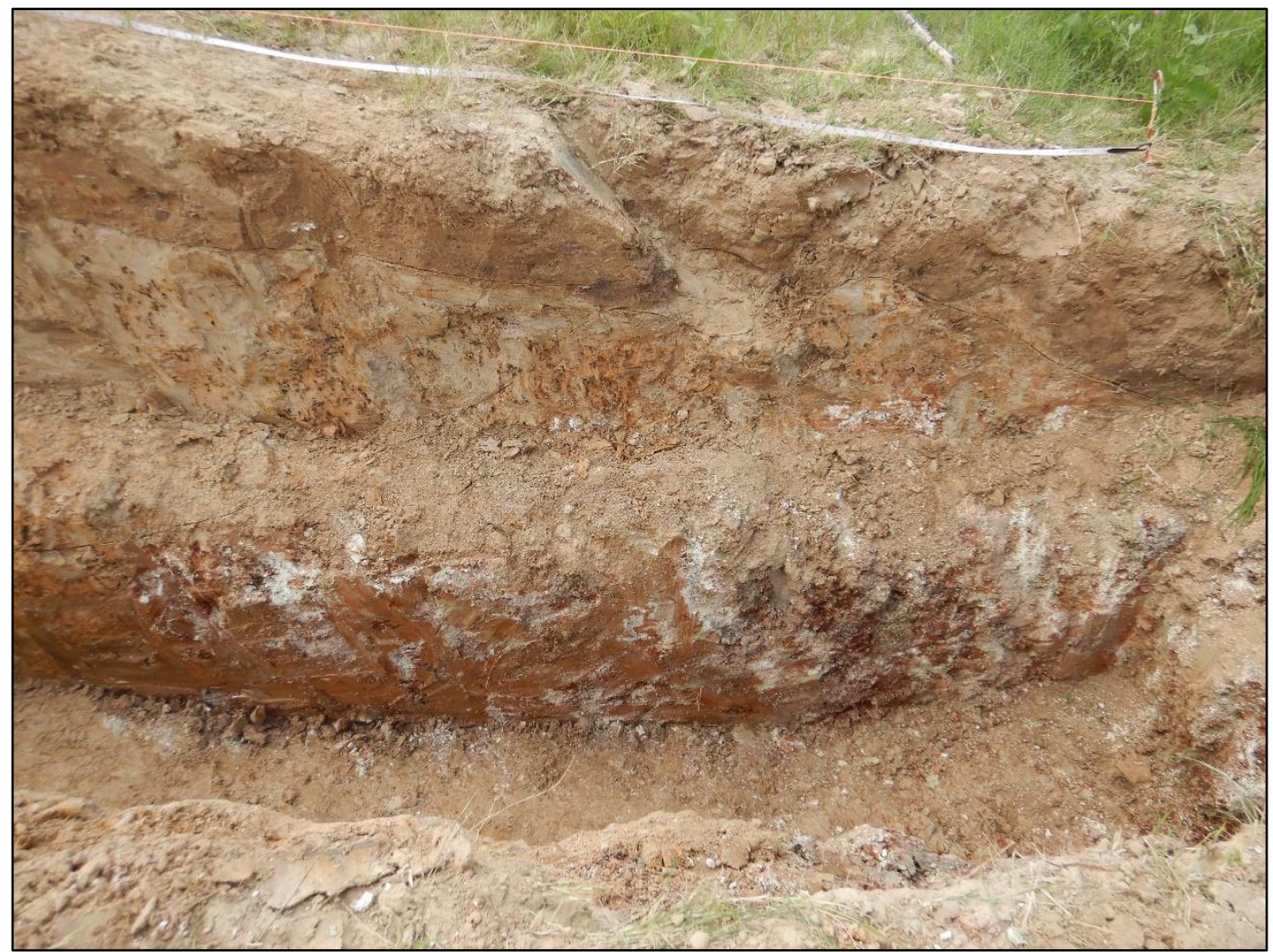

Figure 15. Northern extent of Trench 6 (facing west).

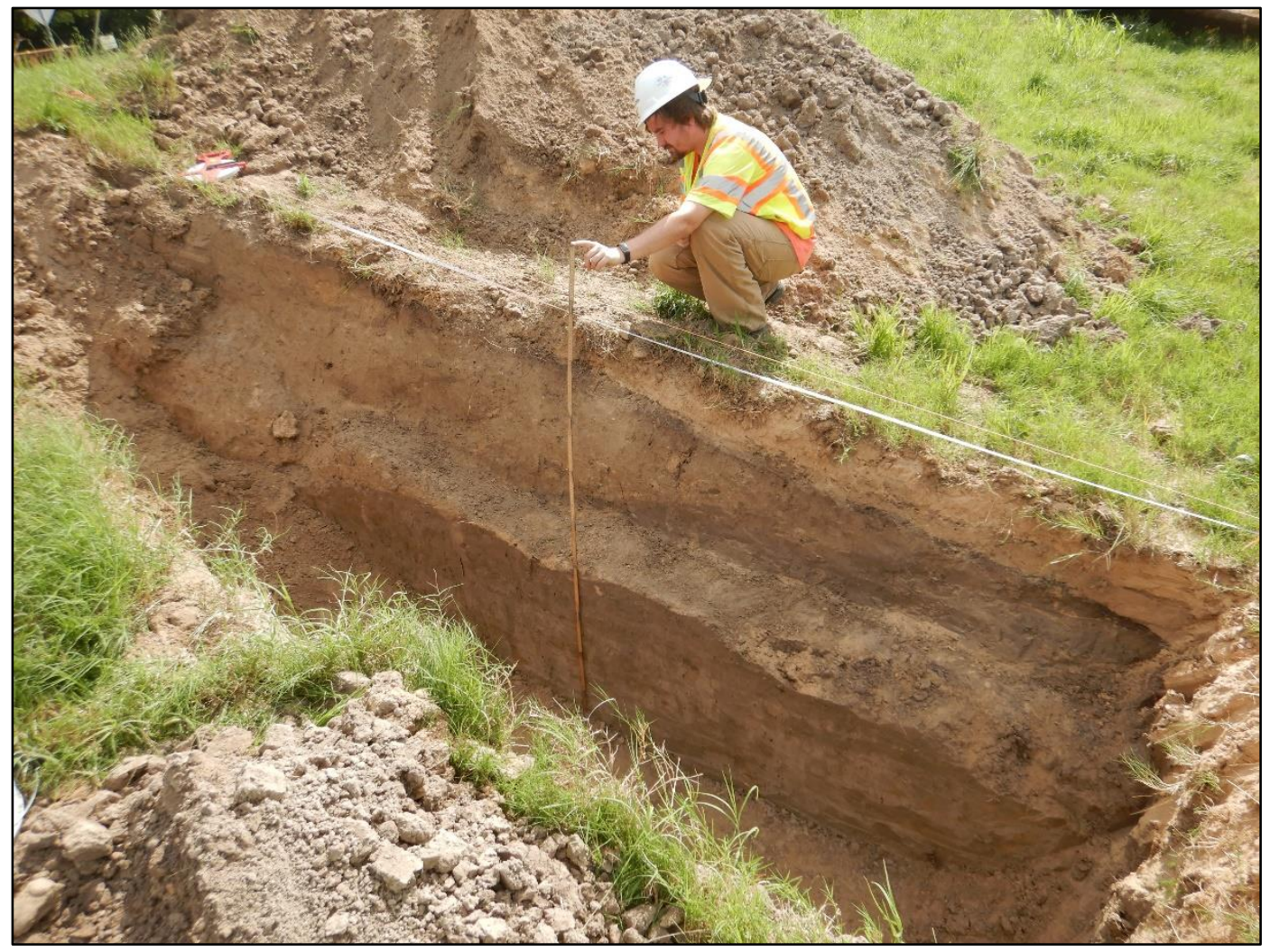

Figure 16. Trench 7 (facing northeast). 


\section{7lerracon}
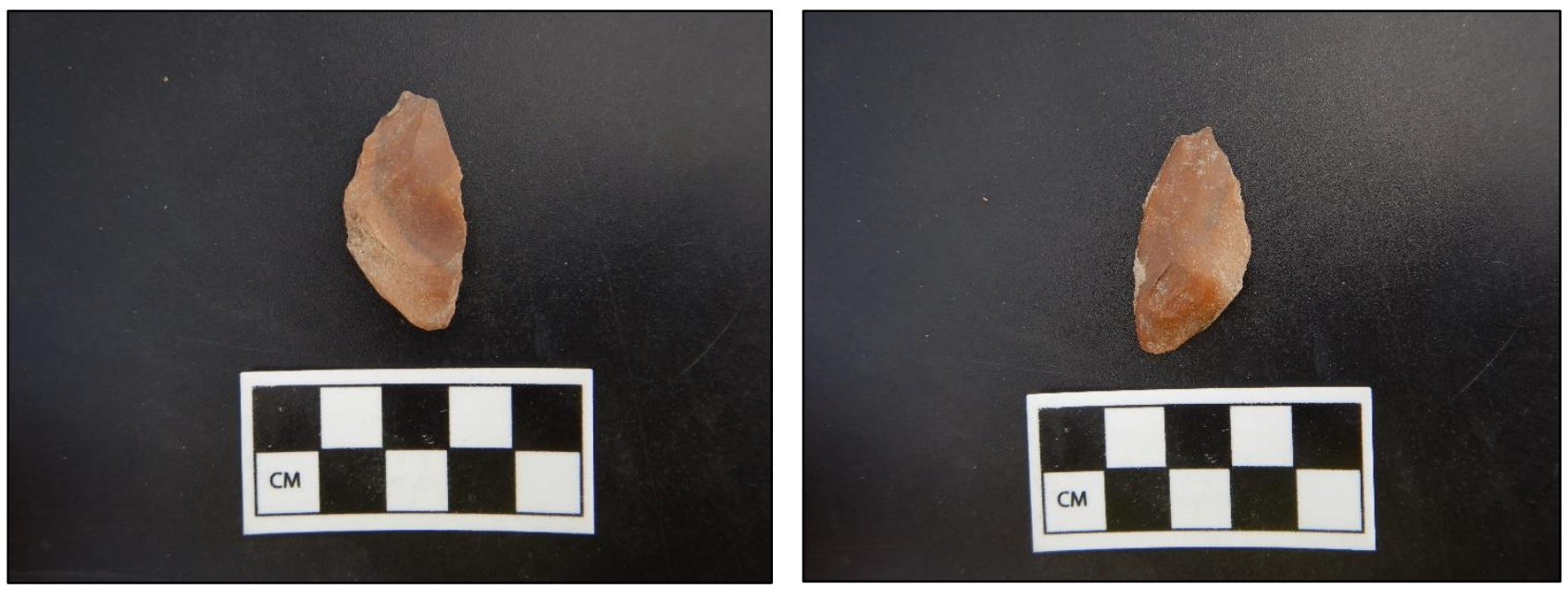

Figure 17. Ventral (left) and dorsal (right) surfaces of chert flake from Trench 7.

Trench 8: This trench was orientated north/south and was located near the northwest corner of the project area (Figure 18). It was placed approximately halfway up the bank. Stratum I consists of dry, friable light yellowish-brown alluvial sand with clay inclusions. Stratum II is a compact grayish brown sandy clay loam subsoil with approximately 30 percent redoximorphic staining and small iron concretions. No cultural materials were identified in Trench 8.

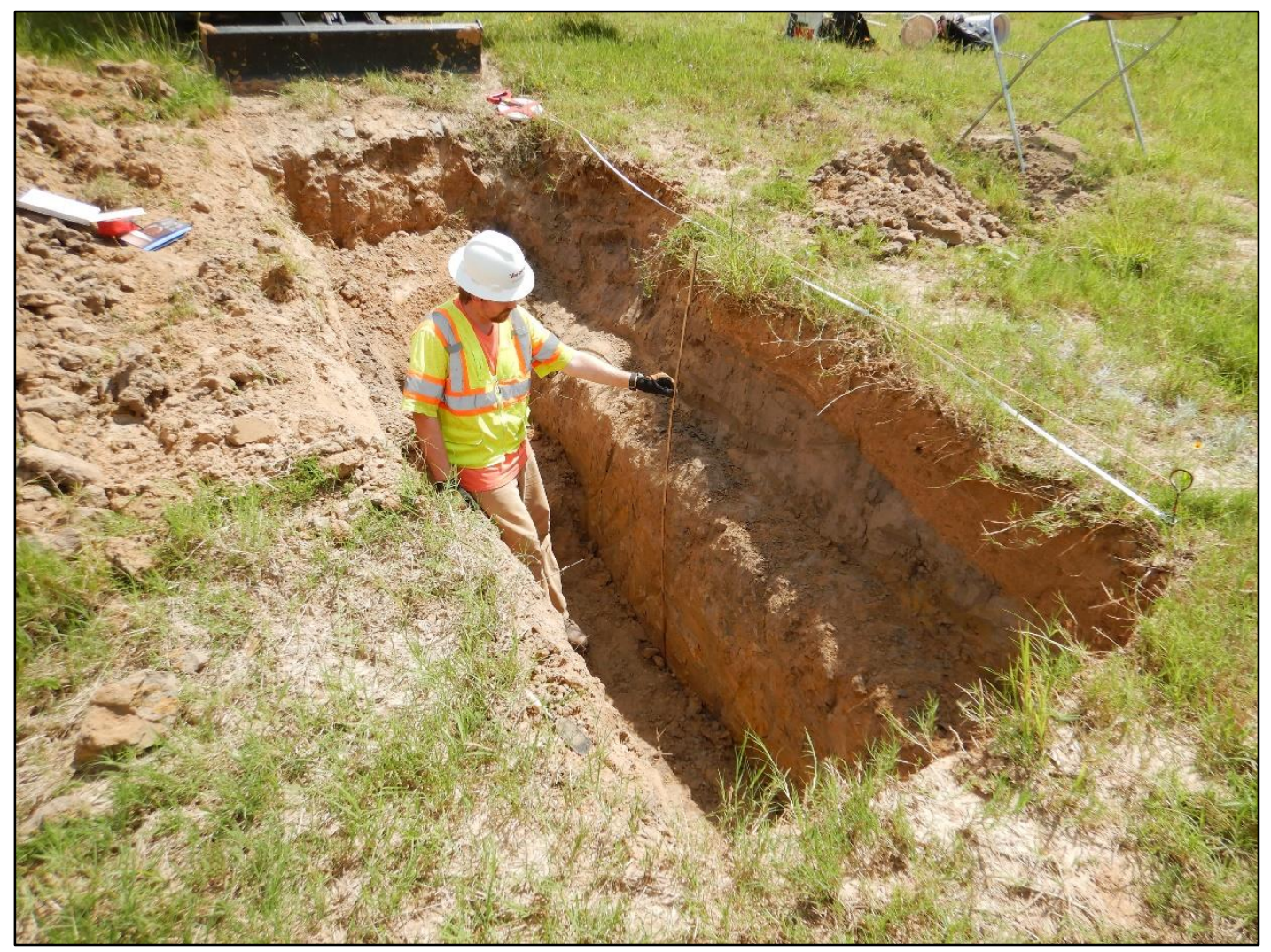

Figure 18. Trench 8 (facing northeast). 


\subsection{CONCLUSIONS AND RECOMMENDATIONS}

Terracon archeologists conducted a desktop review of known recorded cultural resources and a mechanical trenching survey of an approximately nine-acre project area on the banks of Buffalo Bayou at the Peek Road Bridge crossing in the City of Katy, Fort Bend County, Texas. The project area was sampled through the excavation of eight (8) trenches where five 5-gallon buckets of sediment from each trench were screened through $1 / 4$ " screen mesh for cultural materials. One isolated find, a single chert flake from Trench 7, was documented and reburied in a plastic ziplock bag inscribed with the appropriate provenience information.

Based on the results of the investigation, it is Terracon's assessment that no known historic properties eligible for inclusion on the NRHP will be affected by the proposed project. Therefore, Terracon recommends no additional cultural resources studies are warranted at this time. In the event that human remains, historic properties, or buried cultural materials are encountered during construction or disturbance activities, work should cease in the immediate area but can continue where no cultural materials are present. Terracon, the Texas Historical Commission's Archeology Division, or other proper authorities should be contacted. 


\subsection{REFERENCES CITED}

Aten, Lawrence E.

1983 Indians of the Upper Texas Coast. Academic Press, New York.

Brown, Kenneth L.

1994 Material Culture and Community Structure: The Slave and Tenant Community at Levi Jordan's Plantation, 1848-1892. In Working Toward Freedom: Slave Society and Domestic Economy in the American South, edited by Larry E. Hudson, Jr., pp. 95-118. University of Rochester Press, New York.

Costa, August G., Anastasia Gilmer, and Eleanor Stoddart 2018 Cultural Background. In Excavations at the Luce Bayou Site (41LB42): A Mossy Grove Ridgeline Site in the Lower Trinity River Valley, Southeast Texas, edited by August G. Costa and Anastasia Gilmer, pp. 20-33. Report of Investigations Number 658, Moore Archeological Consulting, Inc., Houston.

Griffith, G.E., S.A. Bryce, J.M. Omernik, J.A. Comstock, A.C. Rogers, B. Harrison, S.L. Hatch, and D. Benzason 2007 Ecoregions of Texas. U.S. Environmental Protection Agency, Corvallis.

Lohse, Jon C., editor 2013 Underwater Archeology at 41HY147, the Terrace Locality at Spring Lake. Archeological Studies Report No. 28. Center for Archeological Studies, Texas State University-San Marcos.

Ott, Virginia L.

2018 Fort Bend County. Handbook of Texas Online. Electronic resource, https://tshaonline.org/handbook/online/articles/hcf07, accessed May 30, 2019.

Patterson, Leland W. 1995 The Archeology of Southeast Texas. Bulletin of the Texas Archeological Society 66:239-264.

Ricklis, Robert A.

2004 The Archeology and Native American Occupation of Southeast Texas. In The Prehistory of Texas, edited by Timothy K. Perttula, pp. 181-202. Texas A\&M University Press, College Station.

Story, Dee Ann, Janice A. Guy, Barbara A. Burnett, Martha D. Freeman, Jerome C. Rose, D. Gentry Steele, Ben W. Olive, and Karl J. Reinhard 1990 The Archeology and Bioarcheology of the Gulf Coastal Plain: Volume 1. Arkansas Archeological Survey Research Series No. 38, Fayetteville.

Texas Freedom Colonies Atlas 2019 Texas Freedom Colonies Atlas. Electronic resource, http://www.thetexasfreedomcoloniesproject.com, accessed May 30, 2019. 
Texas Historical Commission

2019 Texas Archeological Sites Atlas. Electronic resource, https://atlas.thc.state.tx.us/, accessed May 30, 2019.

Thoms, Alston V. 2009 Rocks of Ages: Propagation of Hot-Rock Cookery in Western North America. Journal of Archeological Science 36:573-591.

Thurmond, J. Peter, and Don G. Wyckoff 1999 The Calf Creek Horizon in Northwestern Oklahoma. Plains Anthropologist 44:231250.

United States Department of Agriculture 2019 Web Soil Survey. Electronic resource, https://websoilsurvey.nrcs.usda.gov/app/WebSoilSurvey.aspx, accessed May 30, 2019.

United States Geological Survey 2019 USGS-Pocket Texas Geology. Electronic resource, https://txpub.usgs.gov/txgeology/, accessed May 30, 2019.

Yelderman, Pauline A.

2018 Jaybird-Woodpecker War. Handbook of Texas Online. Electronic resource, https://tshaonline.org/handbook/online/articles/wfj01, accessed April 4, 2019. 


\section{Appendix 1 Trench Profiles}




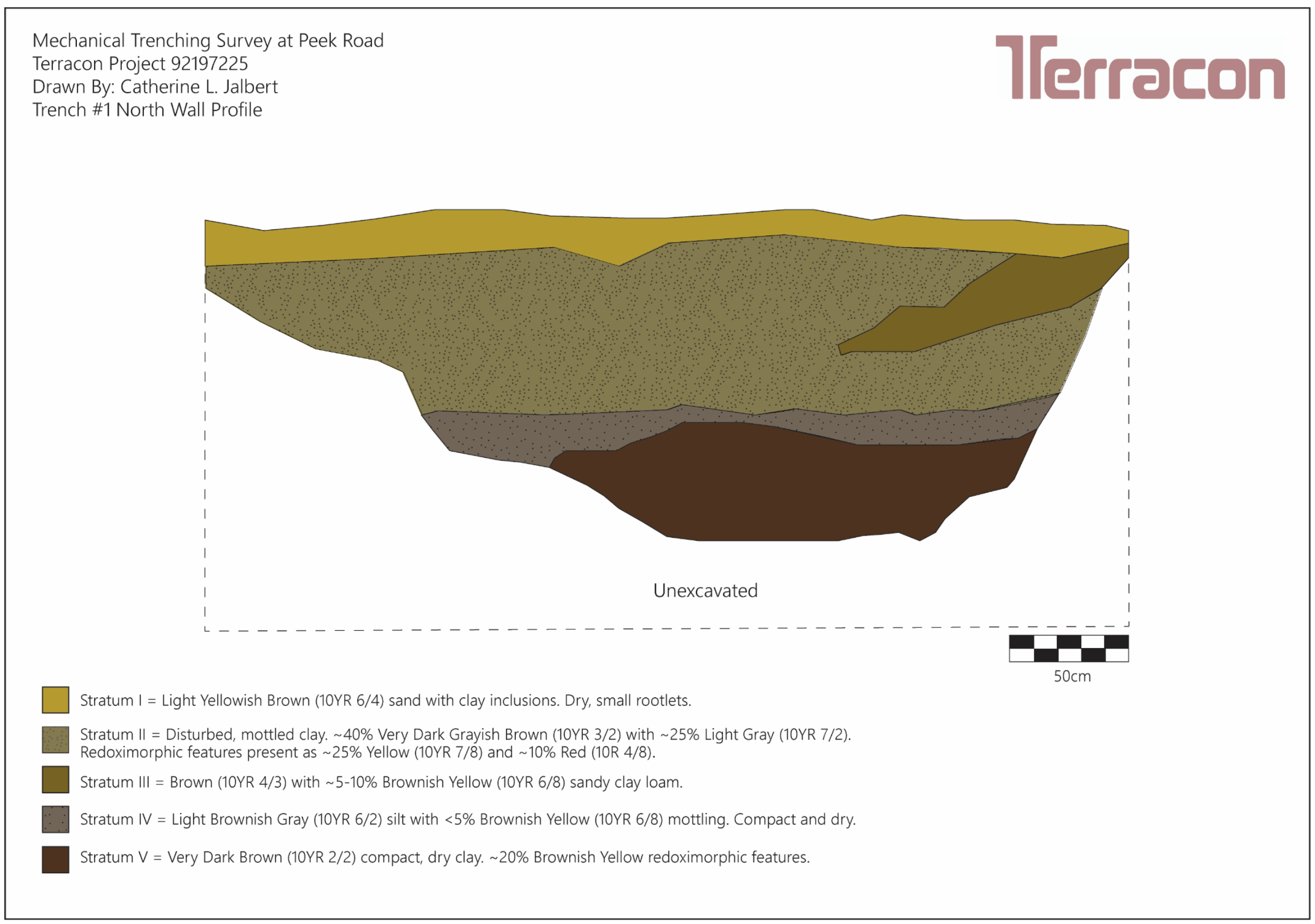


Mechanical Trenching Survey at Peek Road

Terracon Project 92197225

Drawn By: Catherine L. Jalbert

Trench \#2 North Wall Profile

\section{Terracon}

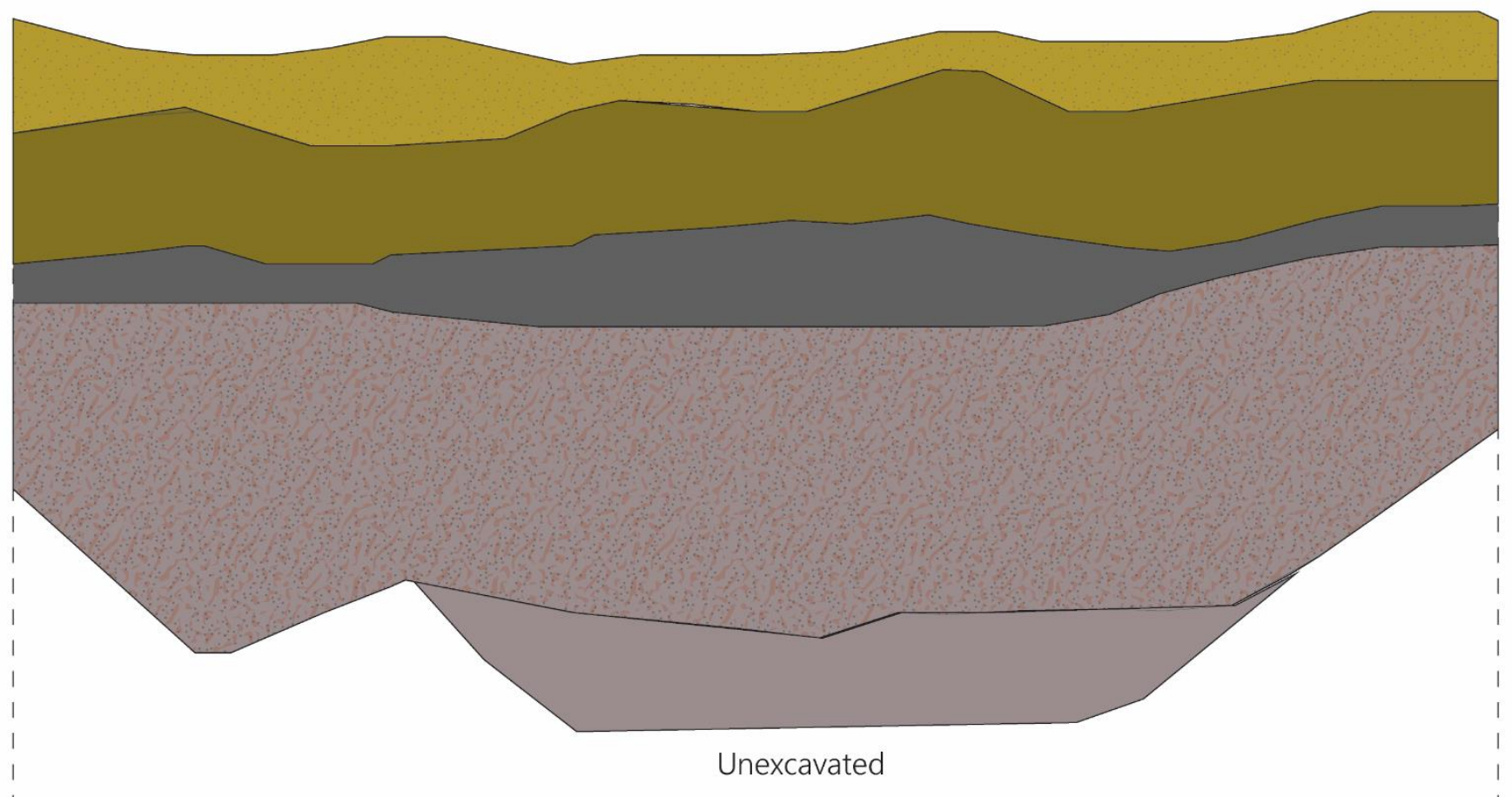

Stratum I = Light Yellowish Brown (10YR 6/4) sand with clay inclusions. Dry, small rootlets.

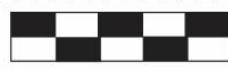

Stratum II = Yellowish Brown (10YR 5/4) sandy clay loam. Slightly moist but friable with some small rootlets.

$50 \mathrm{~cm}$

Stratum III = Very Dark Grayish Brown (10YR 3/2) with 5\% Yellow (10YR 5/8) redoximorphic staining. Moderately compact clay. Dry. sandy clay.

Stratum IV = 30\% Light Gray (10YR 7/2) sandy clay loam with 30\% Very Dark Grayish Brown (10YR 3/2) and 40\% Yellowish Red (5YR 5A). Slight moisture, friable.

Stratum V = Light Gray (10YR 7/2) moist, friable sand. 
Mechanical Trenching Survey at Peek Road

Terracon Project 92197225

Drawn By: Catherine L. Jalbert

Trench \#3 East Wall Profile

\section{Terracon}

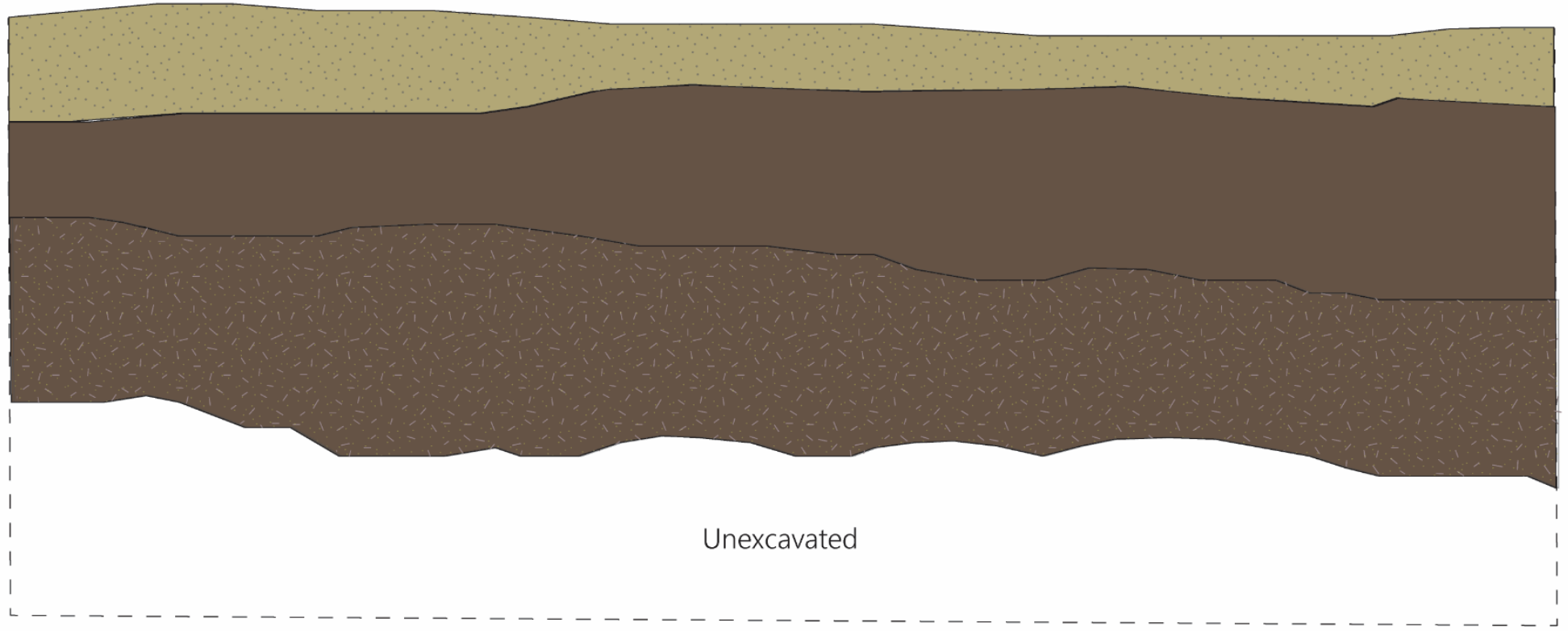

Stratum I = Very Pale Brown (10YR 7/3) sand with clay inclusions. Dry, small rootlets.

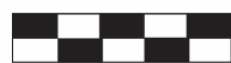

$50 \mathrm{~cm}$

Stratum II = Dark Grayish Brown (10YR 4/2) sandy clay loam. Moist, slightly compact with rootlets, small gravels, and mussel shells throughout.

Modern plastic in this stratum.

Stratum III = Dark Grayish Brown (10YR 4/2) sandy clay loam mottled with 10\% Light Gray (10YR 7/1) and <5\% Yellow (10YR 7/8). 1\% gravels. 


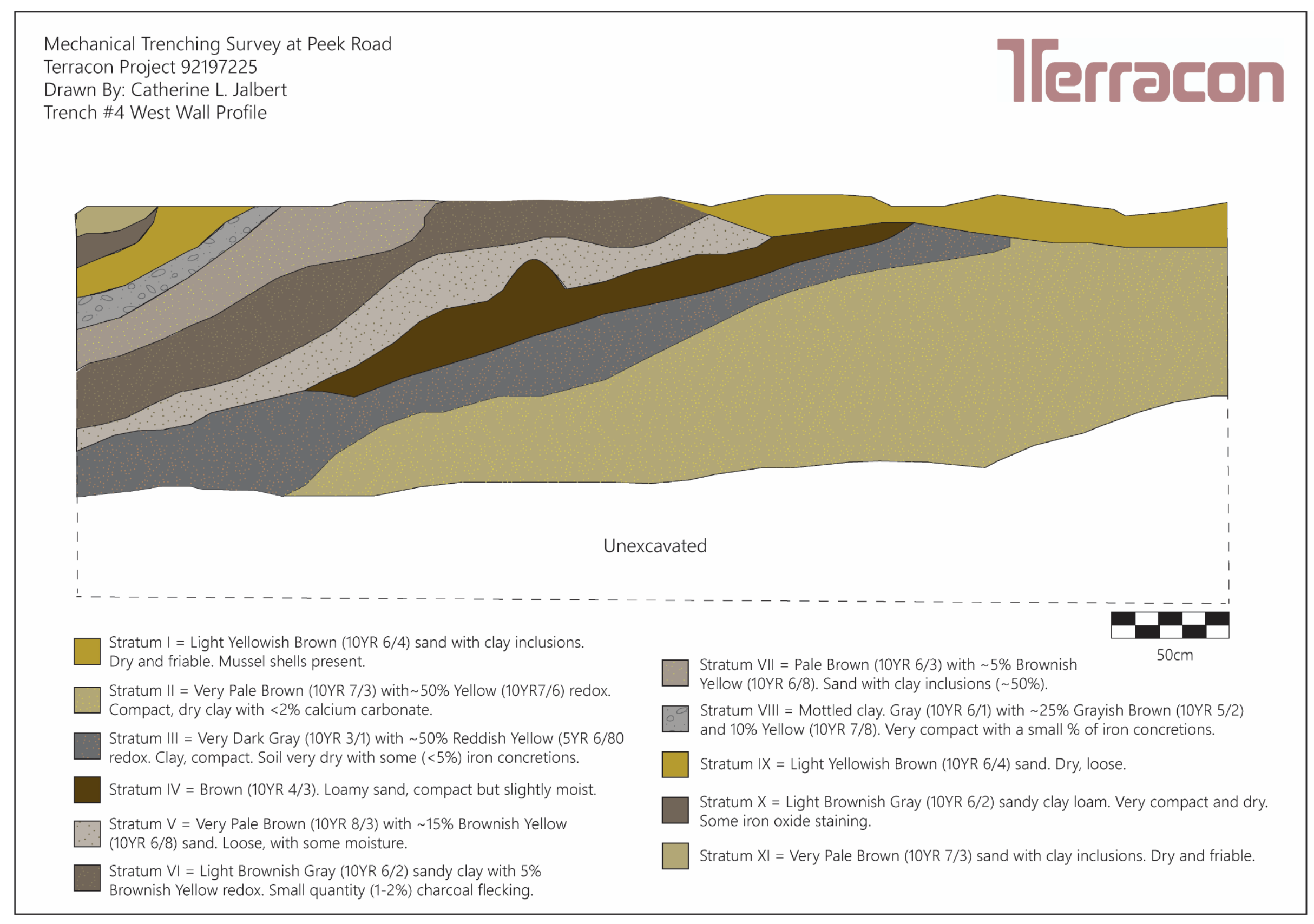


Mechanical Trenching Survey at Peek Road

Terracon Project 92197225

Drawn By: Catherine L. Jalbert

Trench \#5 East Wall Profile

\section{Terracon}

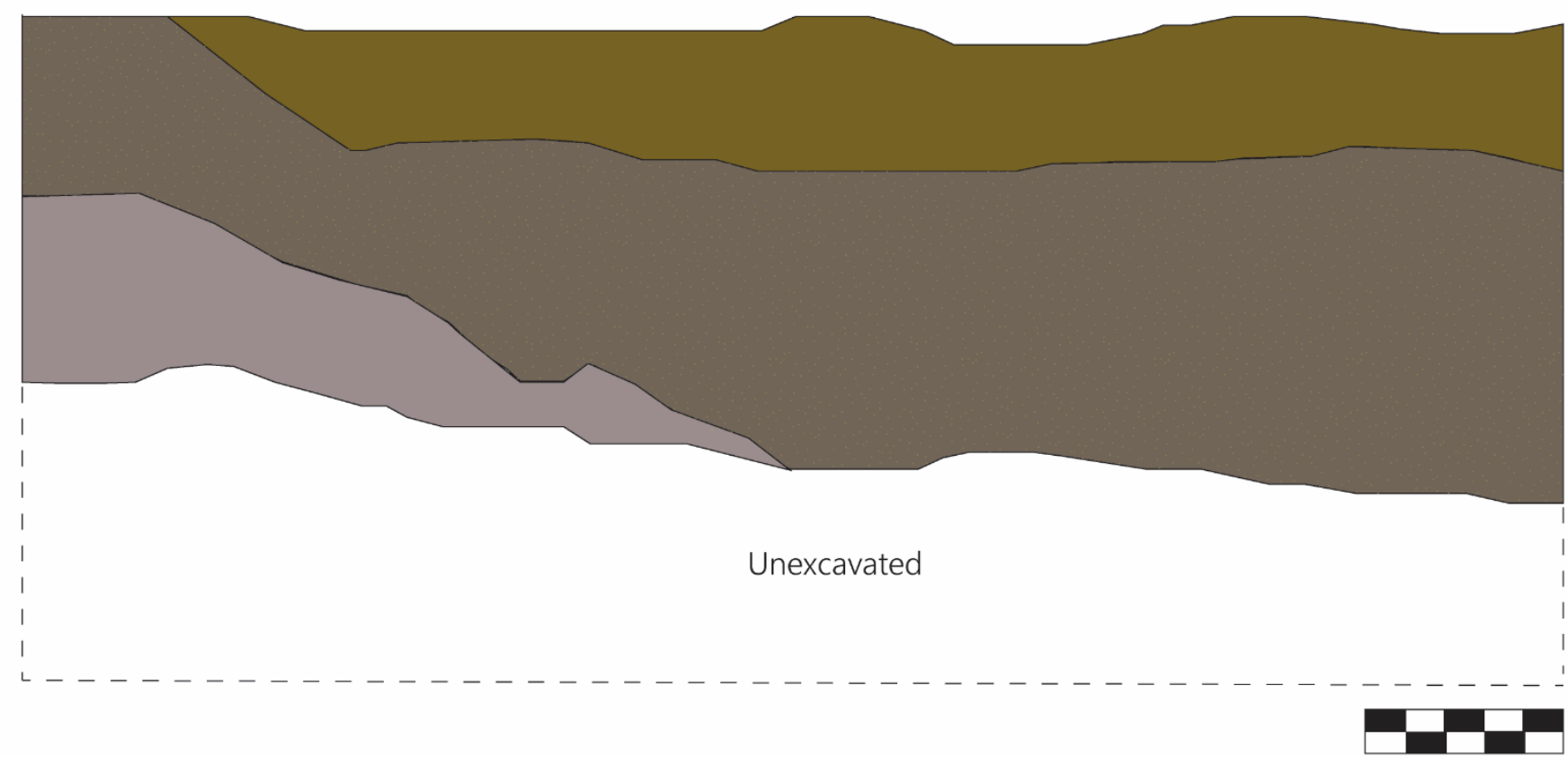

Stratum I = Brown (10YR 4/3) with 5\% Brownish Yellow (10YR 6/8) sandy clay.

$50 \mathrm{~cm}$

Dry and friable with $<3 \mathrm{~cm}$ calcium carbonate concretions. Iron concretions also present.

Stratum II = Light Brownish Gray (10YR 6/2) with 30\% 10YR4/6 Dark Yellowish Brown redox. Dry, compact.

Small percentage $(<5 \%)$ charcoal flecking throughout.

Stratum III = Light Gray (10YR 7/2) moist, friable sand 
Mechanical Trenching Survey at Peek Road

Terracon Project 92197225

Drawn By: Catherine L. Jalbert

Trench \#6 West Wall Profile

\section{Terracon}

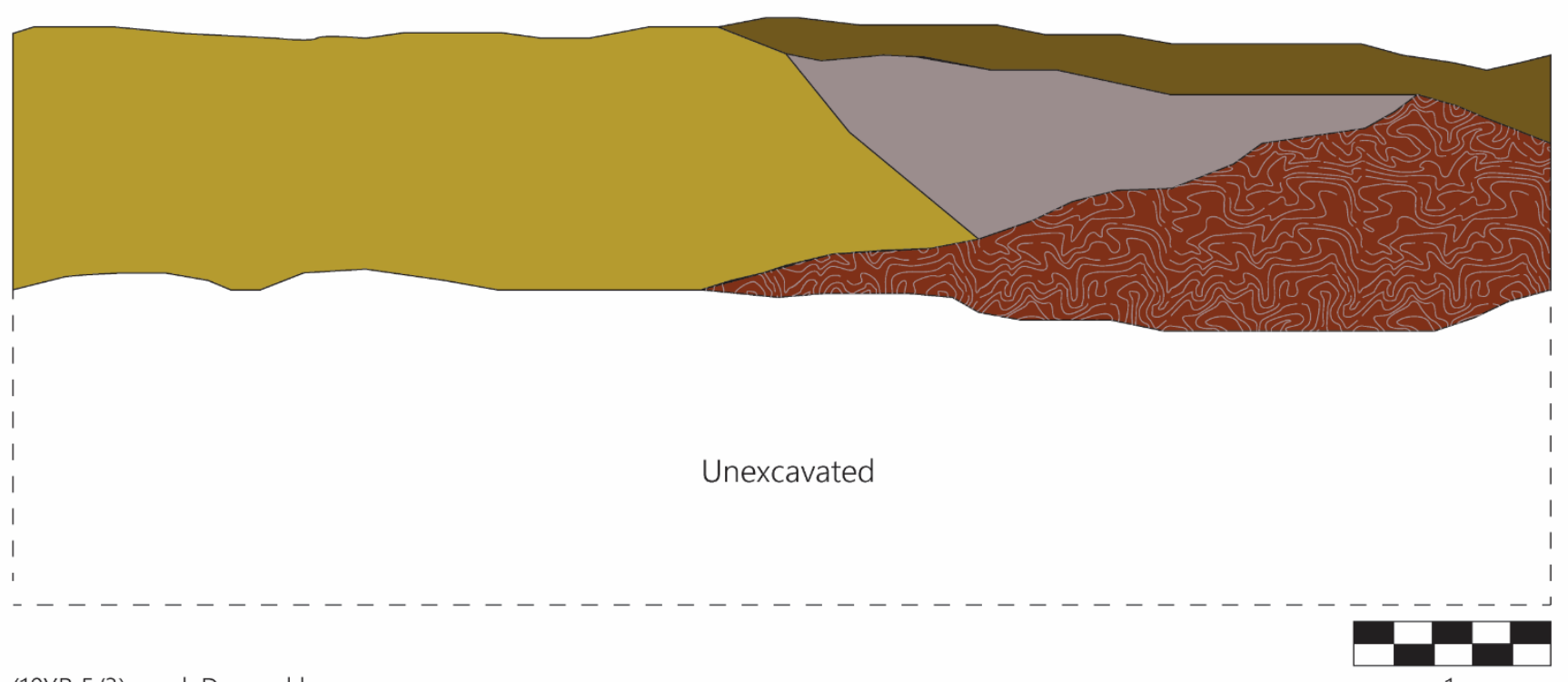

Stratum I = Brown (10YR 5/3) sand. Dry and loose.

$1 \mathrm{~m}$

Stratum II = Light gray (10YR 7/2) sandy clay loam with $\sim 10 \%$ charcoal flecking. Dry and compact. Some iron oxide staining.

Stratum III = Light Yellowish Brown (10YR 6/4) sandy clay loam. Very hard/compact. Small $(<3 \mathrm{~cm})$ iron concretions.

Stratum IV = Red (2.5YR 5/6) clay with 20\% Light Brownish Gray (10YR 6/2) and 10\% White (10YR 8/1) calcium carbonate. Compact soil but slight moisture. 
Mechanical Trenching Survey at Peek Road

Terracon Project 92197225

Drawn By: Catherine L. Jalbert

Trench \#7 East Wall Profile

\section{Terracon}

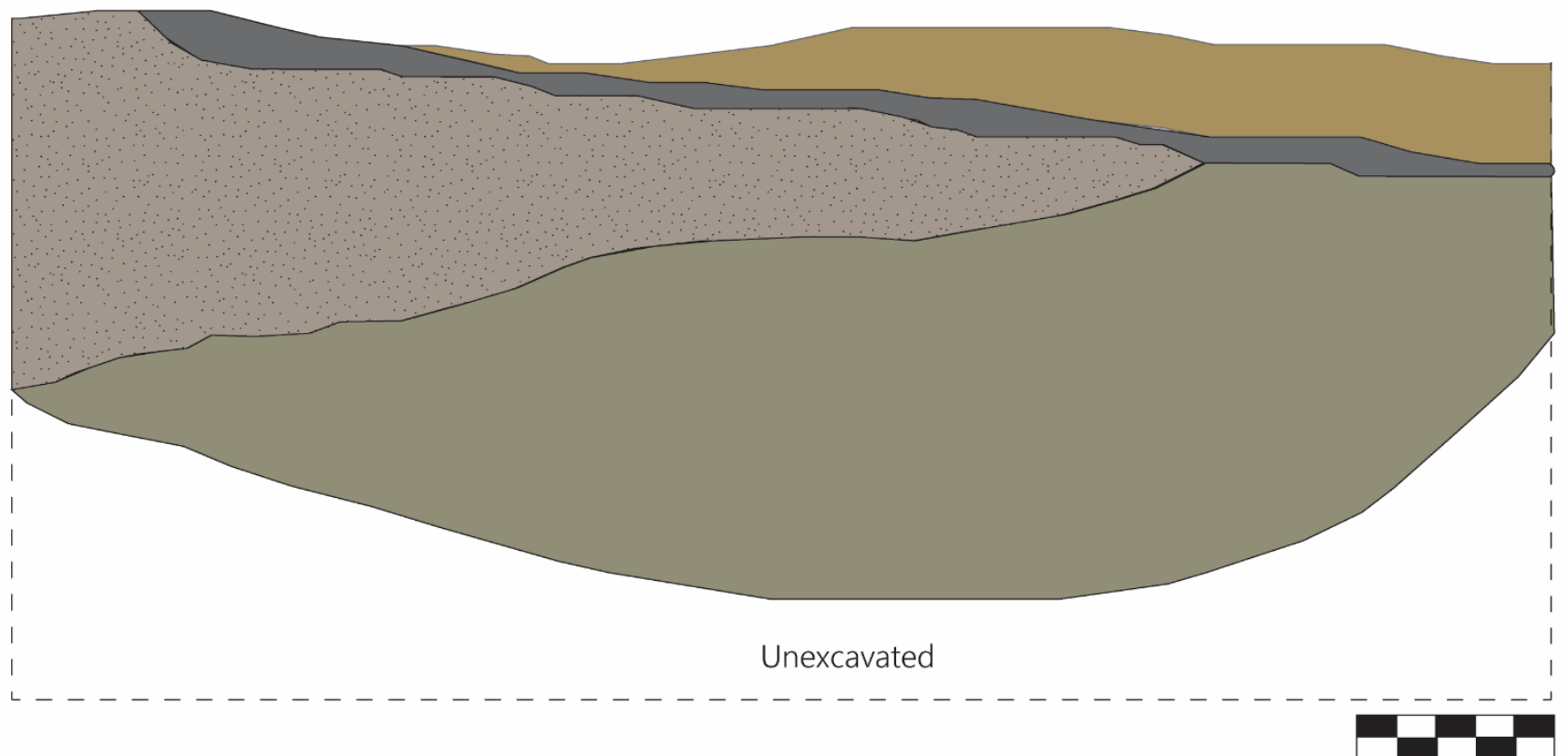

Stratum I = Very Pale Brown (10YR 7/4) sand. Dry and loose.

$50 \mathrm{~cm}$

Stratum II = Very Dark Gray (10YR 3/1) sandy clay loam. Possible buried humic layer.

Stratum III = Fill. Pale Brown (10YR 6/3) sandy clay loam mottled with 10\% Light Gray (10YR 7/2) and 10\% Dark Grayish Brown (10YR 4/2).

Minimal charcoal flecking. Gravels and rocks of varying sizes throughout. Moist soils but compact.

Stratum IV = Grayish Brown (10YR 5/2) sandy clay loam, slightly moist. Charcoal flecking more prevalant than stratum III.

One chert flake recovered from this stratum at approximately $50 \mathrm{cmbs}$ in southern half of trench. 
Mechanical Trenching Survey at Peek Road

Terracon Project 92197225

Drawn By: Catherine L. Jalbert

Trench \#8 East Wall Profile

\section{Terracon}

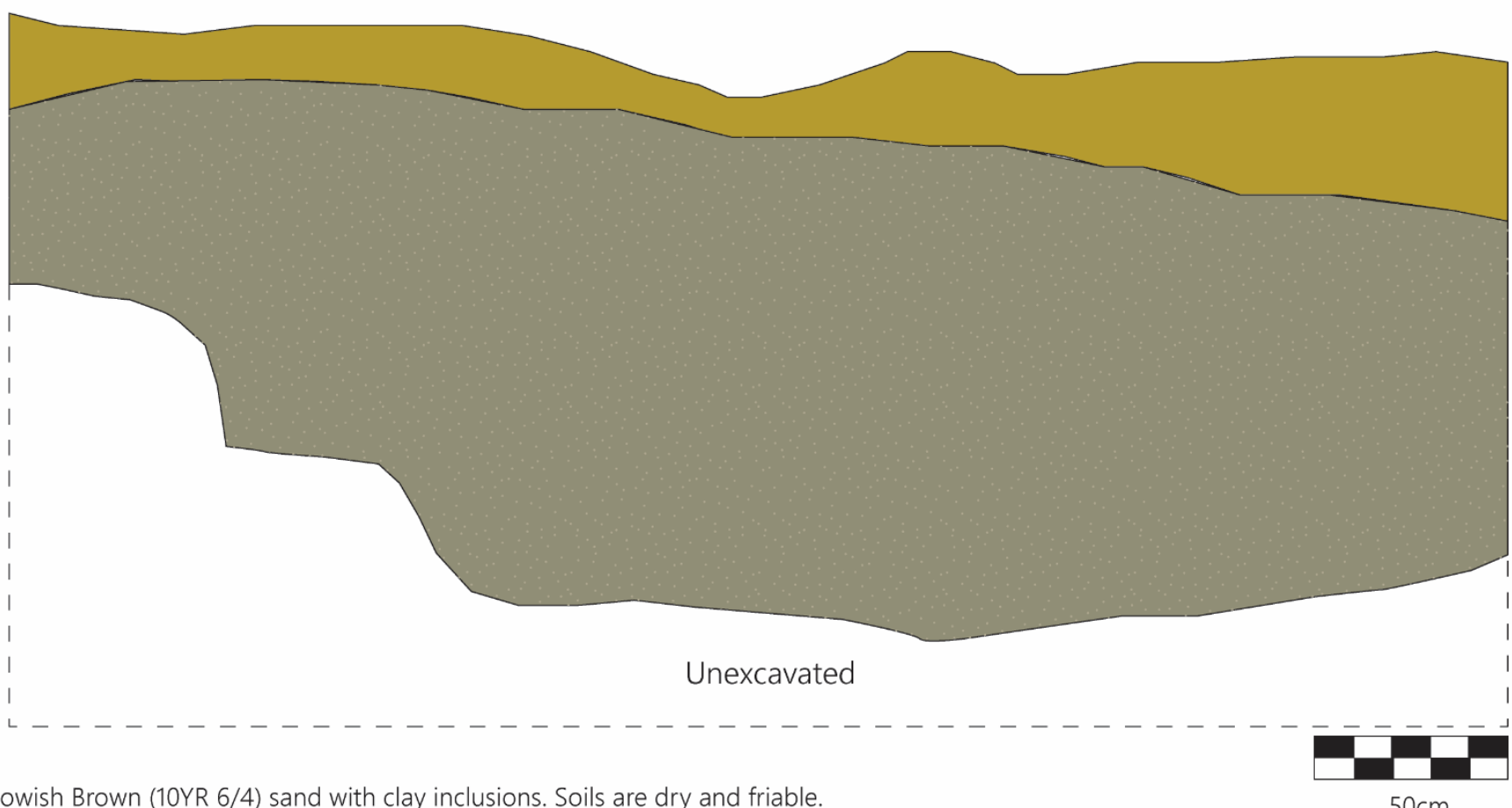

Stratum I = Light Yellowish Brown (10YR 6/4) sand with clay inclusions. Soils are dry and friable.

$50 \mathrm{~cm}$

Stratum II = Grayish Brown (10YR 5/2) sandy clay loam with 30\% Brownish Gray (10YR 6/8) mottling.

Compact with small $(\sim \mathrm{cm})$ iron concretions. 